\title{
MORPHOLOGICAL AND HISTOCHEMICAL TYPE DIFFERENTIATION OF MUSCLE FIBRES IN NEWBORN PIGS: ITS RELATIONSHIP TO TOPICAL MYOPATHIES
}

\author{
J. KAMAN \\ Department of Pathological Morphology, University of Veterinary and Pharmaceutical Sciences, 61242 Brno \\ Received November 12, 1992 \\ Accepted March 30, 1995
}

\begin{abstract}
K a m a n J.: Morphological and Histochemical Type Differentiation of Muscle Fibres in Newborn Pigs: Its Relationship to Topical Myopathies. Acta vet. Brno 1995, 64: 35-47.

Seven topographically and functionally different muscles of neonates of the wild pig, primitive domestic breed and ten modern breeds at various degrees of selection and their hybrids were examined in order to ascertain the degree of muscle fibre differentiation in neonates of the pig as a species. Using myosin ATPase reactions after acid or alkaline preincubation, the author was able to differentiate muscle fibres of type I and II (MF I, MF II), and an intermediary type IIC, with its transformation subtypes mild/strong, strong/strong and strong/mild (MS, SS and SM) in muscle fibres of type I. In some cases, a differentiation of MF II into MF IIA and MF IIB was also observed. SDH detection and PAS reaction failed to differentiate MF in neonatal piglets reliably, or did not differentiate them at all.

Although the degree of MF differentiation in neonatal piglets was mainly determined by their breed, it was also related to their birth weight, MF type and its relationship to the blood bed. Muscle fibres were fully morphologically and adequately histochemically differentiated in the neonatal wild pig, primitive domestic pig, and in the less selected breeds of domestic pigs. Modern medium-selected meat breeds exhibited a myofibrillar deficiency of individual MF at an extent of a physiological variation. Myofibrillar hypoplasia (MFH) at various levels of severity was characteristic of pigs intensively selected for an extreme muscle growth. MFH affected primarily extrafusal anaerobic MF II and muscle groups with a predominance of MF II, for which those pigs have unilaterally been selected. Myofibrillar hypoplasia did not affect intrafusal MF.
\end{abstract}

Neonatal pig, wild pig, muscles, muscle fibre differentiation, classification, myofibrillar hypoplasia

The congenital muscle leg weakness (CMLW) syndrome, or splayleg, of neonatal piglets is one of the most serious breeding and economic problems in contemporary herds. This can be demonstrated by the situation in one of pure-bred Landrace herds, where $50-85 \%$ of litters were affected with almost $40 \%$ intensity and 50\% mortality (S e d l á k 1980). Although splayleg is subject to intensive research, its etiology is still not fully understood. From the pathomorphological point of view, it is described as myofibrillar hypoplasia (MFH) of various intensity ( $\mathrm{T} \mathrm{h}$ u r l e y and D o $\mathrm{n}$ e 1969), or myofibrillar retardation (MFR) ( $\mathrm{K}$ a $\mathrm{m}$ a $\mathrm{n}$ et al. 1977). It has been demonstrated, however, that varying degrees of myofibrillar deficiency (MFD) in muscle fibres are manifested not only in splayleg piglets, but also in controls without any manifested clinical CMLW syndrome ( $\mathrm{S}$ w a t $\mathrm{l}$ a n d 1975; K a $\mathrm{m}$ a $\mathrm{n}$ et al. 1977; Ze le $n$ á and J i r m a n o vá 1979; W a r d 1980; L u ká šet al. 1982). Pi v n ík and $\mathrm{K}$ a $\mathrm{m}$ a $\mathrm{n}$ (1975) considered that as a subclinical form of the CMLW syndrome. J i r m a n o v á (1983) reported that the damage in controls was less extensive. $\mathrm{S} w$ a t $\mathrm{l}$ a n d (1975) and C o x et al. (1979) made an attempt at quantifying MFH in piglets with and without clinical symptoms of CMLW, but their results were not satisfactory. Neither did B r a d l e y et al. (1980) and B u č e k et al. (1982) find any significant differences, even at an ultrastructural level, between the two groups of piglets.

In their report on histochemical characteristics of normal and splayleg neonatal piglets, L u k á š et al. (1978) and H a n z lí k o vá (1980) made no mention of MFD, and demonstrated fully morphologically differentiated MF, similarly as S u z u k i and C a s s e n s (1980) in their MF type differentiation study in neonatal piglets. B e e r $m$ a $n \mathrm{n}$ et al. (1978) described 
fully differentiated muscle fibres not only in neonatal piglets, but, similarly as A s $\mathrm{h}$ m or e et al. (1973), also in foetuses from a late period of gestation. K a m a $n$ (1993) reported a complete morphological and histochemichal differentiation in neonatal pigs of a primitive Vietnamese breed. S c h l o t $\mathrm{k}$ e and $\mathrm{K} \mathrm{o} \mathrm{ch}$ (1978), on the other hand, considered MFD in muscle fibres of meat pigs as common, and L o j d a et al. (1983) and M e s á r o š et al. (1981) as "partially, if not entirely, physiological" phenomenon.

In other words, the hypoplastic condition of myofibrils in MF is being defined by a reference to their normal condition, which is unknown or defined by contradictory data. The aim of our study therefore was: (1) To study the morphological and histochemical differentiation of muscle fibres in the neonates of pigs as a species, from the wild pig to the primitive domestic breed and contemporary breeds of the meat type and their hybrids; (2) To find any relationship between such differentiation and the splayleg syndrome in neonates and postnatal "load" myopathies; (3) To test current histochemical methods and identify one which would be a reliable technique for MF type differentiation; (4) To help clarify some of existing discrepancies in the data on the development of the neonatal muscle fibre.

\section{Materials and Methods}

Using morphological and histochemical techniques, type differentiation of muscle fibres was studied in the neonates of the wild pig, primitive domestic Vietnamese breed, and ten other breeds and their hybrids, mostly of the meat type, that are raised in the Czech Republic. Initially, 19 topographically and functionally different muscles, as given in separate findings, were studied, of which a group of seven muscles (m. longissimus dorsi, $\mathrm{m}$. trapezius, m. triceps brachii, caput longum, m. gracilis, m. semimembranosus, $m$. tibialis cranialis, $m$. sternomastoideus) from 39 neonates was selected. A large majority of them (33) were bioptates, removed under general ether anaesthesia, at the age of 1 to 27 hours post natum.

Half of each excision was frozen to about $-190^{\circ} \mathrm{C}$, and $10 \mathrm{~mm}$ thick cryostat sections were made. Histochemical and type differentiation of muscle fibres was made on serial sections by detecting myosin ATPase activity after alkaline (pH 9.2; 9.4) or acid (pH 4.3; 4.6) preincubation (D u b o w i t $\mathrm{z}$ and B r o o k e 1973; L o j d a and $\mathrm{P}$ a p o u s e $\mathrm{k}$ 1978). The level of oxidative metabolism was examined by succinate dehydrogenase activity (SDH) assay and the glycogen distribution by the periodic acid Schiff (PAS) reaction. The other half of each bioptate was fixed in a neutral $10 \%$ formaldehyde solution. To determine MF morphological differentiation, 8-10 mm thick sections were prepared and stained with hematoxyline-eosin (HE) or toluidine blue.

Some experimental material was used to map the situation in MF development immediately before parturition. A study was made of $\mathrm{m}$. semimembranosus of seven hybrid foetuses (German Large White $\mathrm{x}$ Landrace) obtained from seven sows by a caesarian section between days 113 and 114 of gestation. Muscle excisions were processed by a standard histological technique. Of the many nomenclatures used for MF type differentiation, we chose the terminology proposed by $\mathrm{B} \mathrm{r}$ o o $\mathrm{k}$ e and $\mathrm{K}$ a i s e $\mathrm{r}(1970)$. To differentiate between conversion subtypes, terminology of S u zu ki and C a s s e n s (1980 a) was used. A full MF differentiation is identified by a " + " sign. Myofibrillar hypoplasia (MFH) is assessed on a 1-to-4 scale, where 1 = very weak, 2 = weak, $3=$ moderate, and $4=$ severe. Intermediate degrees are expressed by a " - " sign, the variation range in one muscle is expressed in a range of $+1-4$.

\section{Results}

\section{Sus scrofa}

Three neonates were examined ( 2 females and 1 male), weighing 780-1100 g. Muscles: M. longissimus dorsi - transversal histological cross-sections (CS) demonstrate a complete morphological differentiation of muscle fibres (MF), entirely filled with myofibrils with subsarcolemally localized nuclei (Plate XIV., Fig.1). Most of them are tightly packed together, which accounts for their polygonal CS. The difference in thickness between the primary and secondary populations of MF (MF I and II respectively) has almost been obliterated. The muscle is mostly so compact that primary - and sometimes even secondary - muscle bundles (MB) are not clearly delineated. In more superficial portions, the muscle becomes less compact, with primary bundles clearly distinguishable. Compared to secondary fibres, the primary MF in their centre is usually markedly thicker and, in some rare cases, with a still centrally positioned nucleus. 
Neuromuscular spindles (NMS) are consistently fully differentiated. They contain 1-2 thicker muscle fibres and 3-8 fibres, which are 2 or 3 times thinner. Intrafibral cell nuclei are common.

Myosin ATPase detection after acid as well as alkaline preincubation is highly positive. The myosin reaction after alkaline preincubation (Plate XVI., Fig.5b) reveals 1-2 weakly reacting, often markedly thicker, alkaline-labile primary MF I in the centre of the primary MB. The rest of the bundle is composed of 8-25 strongly reacting alkaline-stable secondary MF II. Close to MF I, 1 or 2 fibres may quite frequently be identified. They represent, in thickness and reaction intensity, a transition between MF II and I. They are intermediary MF of the IIC type.

The myosin ATPase reaction after acid preincubation at pH 4.3 (Plate XVI., Fig. 5a) is a differentiated inversion of the ATPase reaction after alkaline preincubation. In some places, it is possible to differentiate 4 to 5 degrees of ATPase reaction intensity. In the primary MB, a strong reaction is observed not only in MF I, but also in a group of 2-4 MF of the IIC type which are localized around MF I. We consider them conversion subtypes MS, SS and SM of the intermediary IIC type. From the IIC type, they are transformed to type I, from the SM to SS subtypes to the SM subtype, which is a MF I precursor. The MS subtype exhibits a weak reaction after acid preincubation and a strong one after alakaline preincubation, the SS subtype a strong reaction in both cases, and the SM subtype a strong reaction after acid preincubation and a weak one after alkaline preincubation. Other secondary MF of the primary MB are of type II, which may, to a different degree, be differentiated in neonates into MF IIA and IIB (Plate XVII., Fig. 6). Generally, muscle fibres of type II exhibit a strong reaction after alkaline preincubation but negative one after acid preincubation. As the differentiation progresses, the IIA type continues to exhibit no reaction (or a hardly discernible one), while the IIB type exhibits a moderate to medium-strong reaction. After alkaline preincubation, both types exhibit a strong reaction, which may be, however, slightly weaker in the case of the IIA type.

The SDH reaction is highly positive and clearly more constant than the myosin ATPase reaction. Certain muscle fibres corresponding to MF I react with a higher intensity, are more clearly delineated and, to a varying degree, differ from surrounding fibres that correspond to the MF II type. They do not allow an objective type identification.

M. trapezius is even more comprehensively differentiated than the m. longisimus. An ATPase reaction after preincubation at pH 9.4 (Plate XIX., Fig. 9b) can differentiate three degrees of intensity that correspond to the differentiation into MF I, II and IIC. After preincubation at $\mathrm{pH} 4.3$, we can easily differentiate between 4 degrees of reaction (Plate XIX., Fig. 9a), and up to 8 strongly reacting MF of type I and IIC can be found in the primary MB. Even more complicated bundles with up to 14 acid stable MF are also formed.

The SDH reaction is strongly positive, MF are more clearly delineated than in the $\mathrm{m}$. longissimus, but a more accurate type differentiation is still impossible.

M. triceps brachii, caput longum - both extrafusal and intrafusal fibres show adequate signs of complete differentiation. About half of MF have retained their circular CS, but the thickness of both developmental populations of extrafusal MF is already approximately the same. A routine ATPase reaction identified an absolute predominance of strongly reacting MF of type II in the primary MB, with 1-2 weakly reacting MF of type I in its centre. The SDH reaction is usually unambiguously positive, with a degree of differentiation between MF I and II in places (Plate XX., Fig. 10).

M. semimembranosus - an absolute majority of MF is morphologically fully differentiated (Plate XV., Fig. 4), from circular CS in its surface layer to markedly polygonal CSs deeper in the muscle. In the muscle's superficial portion, bundles are clearly delineated, with a more abundant interstitial connective tissue. We observed isolated extremely thick MF of a circular CS in this area (suspected "giant fibres"?). The most differentiated muscle tissue clearly extend along blood vessels. 
The ATPase reaction is not sufficiently defined as yet. In some preparations or parts of them, it cannot be assessed at all. We found that histological sections exhibited a uniform type structure of primary muscle bundles, most frequently with only one MF I in its centre, or they can be divided into three zones. The superficial portion of the muscle contains primary MB with almost exclusively 1 muscle fibre only, the transitional one with 2 to 4 , and the deep portion with 5 to 6 muscle fibres. They exhibit a graded reaction after acid preincubation and a weak one after alkaline preincubation, which indicates a histochemical differentiation in the structure of the m. semimembranosus (Plate XXI., Fig.12).

The SDH reacts positively, although its reaction is weaker compared to other muscles.

M. gracilis - is adequately morphologically differentiated (Plate XV., Fig.3). Muscle bundles are clearly delineated because their contact, just as that of MF, is looser. Relatively thinner MF are mostly of a circular CS.

After alkaline preincubation, the myosin ATPase reaction is often ambiguous. The 1 to 2 muscle fibres located centrally in the MB usually exhibit a weak reaction, others a strong one. Sometimes, the reaction is uniform and does not allow any type differentiation. In spite of that, striation can be observed in longitudinally cut MF. Results after preincubation at $\mathrm{pH}$ 4.3 are more uniform, identifying 1 to 5 intensively reacting MF in the centre of the primary bundle. The SDH reaction is very indicative and in some places helps differentiate between MF I and MF II.

M. tibialis cranialis - cryostatic CS along the entire thickness of this considerably compact muscle exhibit MF fully filled with myofibrils and equipped with other attributes of fully differentiated MF of a mainly polygonal CS.

The ATPase reaction demonstrated a high histochemical differentiation of the muscle, differentiating three MF types after preincubation at $\mathrm{pH}$ 9.4: MF II were dark in colour, while MF I and MF IIC were light and intermediate respectively. A differentiated inversion after preincubation at $\mathrm{pH} 4.3$ identified 4 types: MF II, I and IIC, which included transformation subtypes MS and SS. The most frequent MF found in the primary MB included 3 to 5 strongly reacting muscle fibres of the MF I and IIC types. In aggregate MB, sometimes 9 and rarely even 13 muscle fibres of those types were found. The rest of the primary MB is made up of muscle fibres of type II, which, after preincubation at $\mathrm{pH} 4.6$, may sometimes be differentiated further into MF IIA and IIB. The SDH activity is highly positive and clearly visible even in longitudinal sections.

M. sternomastoideus (Plate XIV., Fig.2) shows a complete morphological differentiation, with MF of a uniform thickness and polygonal CS. While rare in extrafusal MF, the central location of cell nuclei in intrafusal fibres is quite common. The muscle is characterized by a large number of neuromuscular spindles (NMS).

ATPase reactions demonstrate a completed histochemical type differentiation of fibres (Plate XVIII., Figs 8a, 8b). The myosin ATPase activity after alkaline preincubation differentiated 2 to 4 degrees of reaction, with 2 to 10 uniformly or differently weakly reacting alkaline-labile MF in the centre of the primary $\mathrm{MB}$. After preincubation at $\mathrm{pH} 4.3$, it differentiated 4 to 5 types of muscle fibres. In the primary MB, we were able to identify 2 to $16 \mathrm{MF}$ of varying acidostability, representing, for the most part, a majority of the total number of MF in the primary bundle. Although the SDH reaction is unambiguously positive, type differentiation of MF is impossible.

\section{Sus scrofa forma domestica}

Vietnamese Breed

A total of 13 different muscles of 11 newborn piglets (4 females and 7 males), weighing between 250 and $400 \mathrm{~g}$ were examined (see Table 1). 
Table 1

Differentiation of muscle fibres in neonatal pigs of the Vietnamese breed

\begin{tabular}{|c|c|c|c|c|c|c|c|c|c|c|c|c|}
\hline \multirow[t]{2}{*}{ Muscle } & & \multicolumn{11}{|c|}{ Differentiation rating } \\
\hline & Piglet No. & 13 & 14 & 15 & 16 & 20 & 21 & 22 & 23 & 30 & 31 & 32 \\
\hline M. trapezius & & + & + & + & + & + & + & + & + & + & + & + \\
\hline M. longissimus dorsi & & + & + & + & + & + & + & + & + & + & + & + \\
\hline M. triceps brachii, c. lg. & & & & & & & + & + & + & + & + & + \\
\hline M. triceps brachii, c. lat. & & + & + & + & + & & + & + & & & & \\
\hline M. semimembranosus & & + & & + & & + & & + & + & + & + & + \\
\hline M. semitendinosus & & & + & + & + & + & + & + & + & & & \\
\hline M. tibialis cranialis & & + & + & + & + & & & + & + & + & + & + \\
\hline M. sternomastoideus & & & & & & & + & & & & + & \\
\hline M. extensor carpi radialis & & & & & & & & & + & & & \\
\hline M. gracilis & & + & & & & + & & & & & & \\
\hline M. pectoralis transversus & & + & & & & & & & & & & \\
\hline M. rectus femoris & & & & & & + & & & & & & \\
\hline M. gluteus medius & & & & & + & & + & & & & & \\
\hline
\end{tabular}

$+=$ fully differentiated; $+-=$ very weak/negligible $\mathrm{MFH}$

A survey of a full morphological and adequate histochemical differentiation in neonates examined is given in Tab.1. We believe that myofibrillar deficiency in piglets 15 and 31, absolutely insignificant in scope and intensity, is related to their very low weight. The myosin ATPase reaction allowed an identification of MF I and II, intermediary MF IIC and, frequently, of their subtypes MS, SS and sometimes even SM. Less frequently, MF II differentiation into MF IIA and IIB was observed (for more details, see $\mathrm{K}$ a $\mathrm{m}$ a $\mathrm{n}$ 1993).

\section{Duroc Breed}

In addition to the basic set of muscles, the authors also examined the $\mathrm{m}$. semitendinosus from 2 males and 1 females. The piglets, weighing from 1.200 to $1.750 \mathrm{~g}$, came from a breeding herd.

A comprehensive differentiation of MF, both in individual animals and in muscles, exhibited so many similarities that a summary description is possible. Compared to the situation in the wild and the Vietnamese pigs, microscopic analysis showed a higher compactness of the muscle tissue. From the morphological and, in particular, histochemical points of view, muscles may be divided into two groups. The $\mathrm{m}$. longissimus dorsi, $\mathrm{m}$. triceps brachii, $\mathrm{m}$. gracilis, $\mathrm{m}$. semimembranosus and $\mathrm{m}$. semtendinosus are glycolytic in character, with an absolute predominance of MF of type II with 1 to 2 MF I in their primary MB. The remaining muscles, i.e. the $\mathrm{m}$. trapezius and $\mathrm{m}$. sternomastoideus, are, on the other hand, characterized by a higher percentage of the MF of type I, and, especially, type IIC in their primary MB. Histochemical differentiation corresponds fully to the high degree of morphological differentiation (Plate XIX., Figs 9a, 9b). In spite of a positive and, in places, intensive SDH reaction (Plate XX., Fig.10), only MF I, II and, rarely, IIC were differentiated in muscle fibres. The PAS reaction was largely monotonous. Sporadically, MBs with lower content of glycogen in central, and higher in peripheral MFs were found; glycogen was quite frequently found interfibrally as also interfascicularly.

\section{Hybrid Breed: (Czech Large White x Landrace x Duroc) (CLW x L) x D}

We studied two neonates weighing $1.610 \mathrm{~g}$ (male) and $1.520 \mathrm{~g}$ (female). The dominant feature was a complete morphological and histochemical differentiation of MF in all eight muscles. While the superficial portion of the $m$. longissimus featured sporadic MF with remains of tubular lumina or central nuclei, the $\mathrm{m}$. triceps was characterized by a higher compactness of its muscle tissue, and the $\mathrm{m}$. gracilis by a looser contact between muscle bundles and fibres. Sporadic MF of type II incompletely filled with myofibrills were found in superficial portions of the $\mathrm{m}$. semimembranosus and $\mathrm{m}$. semitendinosus, with a tendency to 
a monotonous histochemical reaction. In type differentiation, on the other hand, deep portions of these muscles showed a tendency to similarities with the $\mathrm{m}$. trapezius, $\mathrm{m}$. tibialis cranialis and $\mathrm{m}$. sternomastoideus, which were the most completely differentiated muscles. With a routine ATPase reaction we were able to identify 1 to 5 alkaline-labile and up to 9 acid-stable muscle fibres in their primary muscle bundle.

\section{Czech Large White Breed (CLW)}

This breed was represented by 2 piglets (Nos 41 and 43), a male and a female (1.600 g and $1.330 \mathrm{~g}$ respectively) from a traditional operation, and one male piglet (No.689) weighing $1.100 \mathrm{~g}$ from a large commercial herd.

Table 2

Differentiation of muscle fibres in Czech White Large neonatal pigs

\begin{tabular}{|c|c|c|c|c|}
\hline \multirow[t]{2}{*}{ Muscle } & \multicolumn{4}{|c|}{ Differentiation rating } \\
\hline & Piglet No. & 41 & 43 & 689 \\
\hline $\begin{array}{l}\text { M. longissimus dorsi } \\
\text { M. trapezius } \\
\text { M. triceps brachii, caput longum } \\
\text { M. gracilis } \\
\text { M. tibialis cranialis } \\
\text { M. sternomastoideus } \\
\text { M. semimembranosus }\end{array}$ & & $\begin{array}{l}1 \\
+ \\
+ \\
+ \\
+ \\
+ \\
1-2\end{array}$ & $\begin{array}{l}+ \\
+ \\
+ \\
+ \\
+ \\
+\end{array}$ & \pm \\
\hline
\end{tabular}

For more details on the numerical rating of the degree of muscle fibre differentiation, see chapter Materials and Methods. The same method was used in all tables.

Table 2 shows that MF in most of the muscles were fully morphologically differentiated. Sporadically, some MF or sites with a few MF not completely filled with myofibrils were found. In scope and intensity, myofibrillar hypoplasy was most readily identifiable in piglet No.41, particularly in its $\mathrm{m}$. longissimus dorsi and, even more so, in its $\mathrm{m}$. semimembranosus. The SDH reaction, positive in the $\mathrm{m}$. longissimus dorsi and blurred in the $\mathrm{m}$. semimembranosus, did not allow MF type differentiation. The best MF type differentiation was possible by the ATPase reaction after acid preincubation. After alkaline preincubation, the ATPase reaction was weaker, particularly in the $\mathrm{m}$. semimembranosus.

\section{Belgian Landrace Breed (BL)}

One male piglet weighing $1.600 \mathrm{~g}$ from a breeding herd was examined. Most of the muscles (m. träpezius, $\mathrm{m}$. triceps brachii, $\mathrm{m}$. gracilis, $\mathrm{m}$. sternomastoideus and $\mathrm{m}$. tibialis cranialis) exhibited all signs of full morphological differentiation. The $\mathrm{m}$. longissimus and the $\mathrm{m}$. semimembranosus, similarly as in the CLW breed, were affected by very weak MFH. Histochemical reactions of the myosin ATPase, with the exception of a monotonous reaction after alkaline preincubation in the $\mathrm{m}$. semimembranosus, were generally highly positive (Plate XVIII., Fig. 8a, 8b). Fluctuations in ADH reactions, particularly in MF II identification, did not allow MF type differentiation.

\section{Slovak Meat White Breed (SMW)}

Two male and 1 female neonates from a commercial large-scale operation were studied, weighing 1.300 to $1.400 \mathrm{~g}$.

The animals came from a herd with a history of the CMLW syndrome but from litters which were not affected by it. In piglet No. 273 , all seven muscles were examined. In the remaining animals, only one muscle of each animal was used for histological examination. Data in Tab. 3 show a modest to locally very severe myofibrillar deficiency in all muscles studied, with the exception of the m. gracilis in piglet No. 692 . 
Table 3

Differentiation of muscle fibres in Slovak White Large neonatal pigs

\begin{tabular}{|c|c|c|c|c|}
\hline \multirow[t]{2}{*}{ Muscle } & & \multicolumn{3}{|c|}{ Rating } \\
\hline & Piglet No. & 273 & 690 & 692 \\
\hline $\begin{array}{l}\text { M. longissimus dorsi } \\
\text { M. triceps brachii, caput longum } \\
\text { M. pectoralis transversus } \\
\text { M. extensor carpi radialis } \\
\text { M. gracilis } \\
\text { M. semimembranosus } \\
\text { M. biceps femoris }\end{array}$ & i & $\begin{array}{l}3 \\
3-4 \\
3 \\
+-2 \\
3 \\
1-4 \\
1-4\end{array}$ & $1-2$ & + \\
\hline
\end{tabular}

\section{Landrace Breed (L)}

Four neonates from traditional operations (two males and two femals), body mass 1.000 to $1.350 \mathrm{~g}$. In addition to the basic set, another five muscles were studied.

Table 4

Diferentiation of muscle fibres in Landrace neonatal pigs

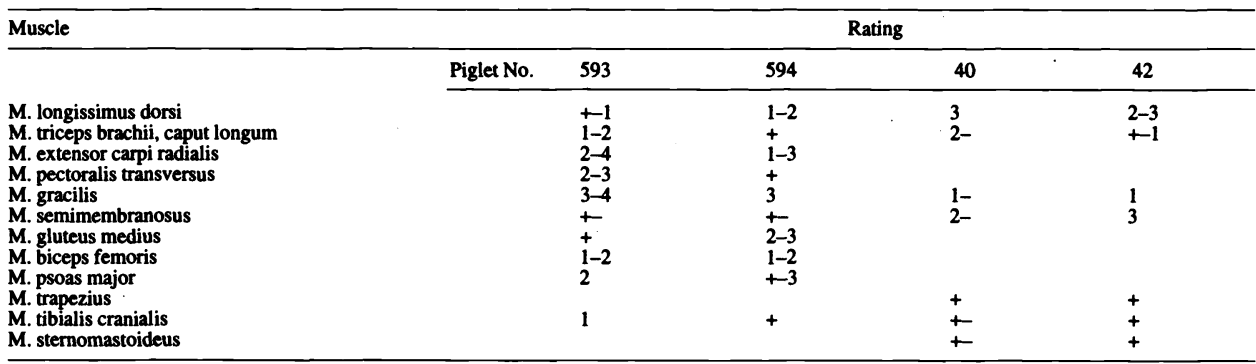

In all the piglets, various degrees of myofibrillar retardation were ascertained. The least and the most affected were piglets No. 42 and 593 respectively, the muscles were the m. trapezius, $\mathrm{m}$. sternomastoideus and $\mathrm{m}$. tibialis cranialis. The degree of MFH differed even among individual fibres. In cases of severe MFH, we were often able to find numerous MF which, under the light microscope, were empty and in a cross-section they were only represented by a sarcolemma, and possibly also a cell nucleus (Plate XXII., Figs 14, 15). Muscle fibres of the second generation (MF II) were affected. In histological sections, areas affected to various degrees alternated with regions almost completely or completely differentiated (Plate XXI., Fig.13).

In muscles with myofibrillar retardation, histochemical differentiation of the MF was also delayed. In ATPase detection, conspicuously better results were obtained after acid compared to alkaline preincubation.

\section{Hybrid Breed: Přestické x Landrace (PY̌ x L)}

One male neonate examined, body mass $1.350 \mathrm{~g}$, from a traditional small herd, HE. The group of muscles in question was examined only histologically. It contained muscles fully morphologically differentiated (m. gracilis, Plate XV., Fig.3), with almost imperceptible myofibrillar hypoplasia, as well as those with pronounced MFH (m. semimembranosus), the intensity of which ranged between degrees 1 and 2 in individual histological sections.

\section{Hybrid Breed: Latvian Large White x German Large White (LLW x GLW)}

One male and one female piglets from a traditional operation were studied, weighing 750 $\mathrm{g}$ each. Bioptates were only examined histologically, using HE. All of the muscles studied were characterized by a predominance of MF II. They exhibited different degrees of MFH, 
similar in both of the piglets. Histological preparations of the same muscle showed fully differentiated areas alternating with those that exhibited moderate to severe degrees of deficiency. Their rating was + - 4. MFH was observed in extrafusal MF of type II, conspicuous for their large amount of centrally positioned cell nuclei. Intrafusal MF were not affected by MFH.

Table 5

Differentiation of muscle fibres in porcine neonates of the hybrid Latvian Large White x German Large White

\begin{tabular}{llc}
\hline Muscle & & Rating \\
\hline & Piglet No. & 742 \\
\cline { 2 - 3 } M. longissimus dorsi & 3 & 743 \\
M. triceps brachii, caput longum & 2 & +-4 \\
M. extensor carpi radialis & 3 & 3 \\
M. pectoralis transversus & +- & $1-2$ \\
M. biceps femoris & 3 & $2-3$ \\
M. gluteus medius & +-3 & 3 \\
M. gracilis & +3 & 3 \\
M. semimembranosus & 3 & $1-2$ \\
\hline
\end{tabular}

Hybrid Breed: Czech Large White x Landrace (CLW x L)

This breed forms the basis of the Czech hybridization program. For this reason, it was the largest group with 6 male and 3 female piglets from 4 different herds. Their body mass ranged from 950 to $1.400 \mathrm{~g}$.

Table 6

Differentiation of muscle fibres in porcine neonates of the hybrid Czech $\mathbf{L W} \times \mathbf{L a n d r a c e}$ breed

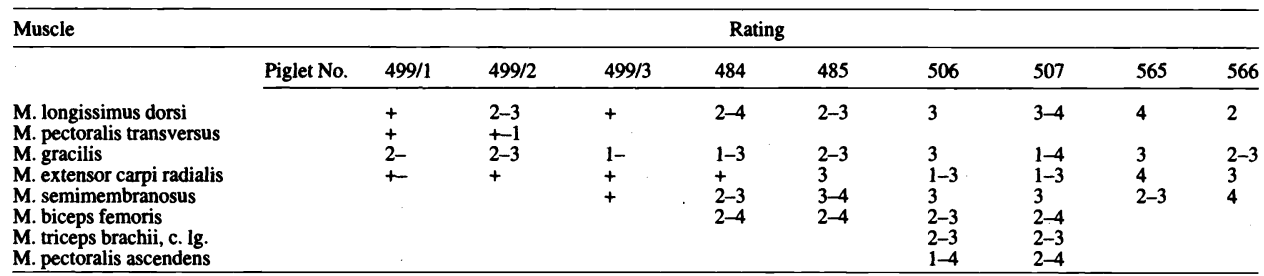

In most of the neonates (Nos 484 - 566), MFH severely affected practically all the muscles examined (Plate XXII., Figs 14, 15), regardless of their different origin. This was in a marked contrast to findings in piglets Nos 499/1 - 499/3 from a traditionally reared herd, where most of the muscles had fibres adequately differentiated (Tab. 6). That demonstrated that the physiological standard in CLW x L neonates were fully differentiated muscle fibres.

Hybrid Breed: German Large White x Landrace (GLWxL)

They were 3 female and 4 male foetuses removed between Day 113 and 114 of gestation, body mass 800 to $1.480 \mathrm{~g}$, excisions from the $\mathrm{m}$. semimembranosus.

Microscopy of histological sections defined three basic structures: a) primary muscle bundles of the neonatal type, b) of the foetal type, and c) primary MB with fibres not completely filled with myofibrils. In most of them, the neonatal type predominated, with muscle fibres fully differentiated. Their CS, however, was still mainly circular, with an already well-defined cross striation in a longitudinal section. Differences in thickness between primary and secondary MF were already small. The foetal type of the primary bundle was characterized by a markedly thicker primary MF compared to the secondary fibres in the centre of the primary bundle, with a still existing myotubule, or, rather, centrally located nucleus. It occurred sporadically or in completely isolated groups. Sporadically occurring muscle fibres or their groups not fully lined with myofibrils were insignificant in scope or intensity. 


\section{Discussion}

From the point of view of morphological and histochemical MF differentiation, the piglets examined may be divided into three basic groups: Group 1 (Tab.7) includes neonates of the wild pig, the primitive Vietnamese breed, the Duroc meat breed and its hybrides (CLWxL) x D, and the German LW x Landrace breed. Their common feature is muscle fibres exhibiting morphological and histochemical differentiation that is adequate to physiological motility of nidifugous mammals. Naturally, the process of differentiation was not uniform. The m. longissimus dorsi, for instance, was relatively less differentiated morphologically, while the $\mathrm{m}$. semimebranosus histochemically. They are muscles from muscle groups for which the meat breeds have been selected, i.e. muscles with an absolute predominance of anaerobic, glycolytic type II fibres. We believe that markedly wider interstitial gaps between primary bundles and also between their MF in the Vietnamese breed compared to strikingly more compact structure of MB in the Duroc meat breed, constitute a characteristic of a primitive breed.

Table 7

List of breeds used in the study of muscle fibre differentiation in porcine neonates

\begin{tabular}{|c|c|c|}
\hline Breed, hybrid & Number & Rating \\
\hline $\begin{array}{l}\text { Sus scrofa } \\
\text { Vietnamese Breed } \\
\text { Duroc } \\
\text { (Czech Large White x Landrace) x Duroc } \\
\text { German Large White x Landrace } \\
\text { Czech Large White } \\
\text { Belgian Landrace } \\
\text { Pfestické x Landrace } \\
\text { Landrace } \\
\text { Slovak Meat White } \\
\text { Latvian Large White x German Large White } \\
\text { Czech Large White x Landrace }\end{array}$ & $\begin{array}{l}3 \\
7 \\
3 \\
2 \\
7 \\
3 \\
1 \\
1 \\
4 \\
3 \\
2 \\
9\end{array}$ & $\begin{array}{l}+ \\
+ \\
+ \\
+ \\
+ \\
+ \\
+ \\
+ \\
+ \\
+ \\
+\end{array}$ \\
\hline
\end{tabular}

$+=$ full differentiation, +- = very week $M F H,-+=$ medium $M F H,-=$ strong $M F H$

A sporadic occurrence of MF incompletely lined with myofibrils in piglets from the CLW, BL and hybrid PCxL breeds was negligible, both morphologically and histochemically, and it may well be included in the physiological scope of developmental variations. The fact that the Pc x L hybrid also meets the requirements for this group is a confirmation of a positive impact of the Přestice breed.

The third group, markedly different from the previous two, includes breeds and hybrids characterized by medium (Landrace and Slovak Large White) to severe (Latvian LW, German LW and Czech LW) degrees of myofibrillar hypoplasia of their muscle fibres. A marked myofibrillar retardation of MF in SLW pigs consists, in our opinion, in the fact that it is a synthetic breed with a large proportion of the Landrace breed, the piglets (as controls to neonates with clinical expression of CMLW) came from herds afflicted with CMLW, but from litters which were not affected by the syndrome.

Analogically, the Landrace breed may perhaps be assumed to have a negative influence on the MF development in the CLWxL hybrid. Within a breed, however, influence of breed lines can clearly be demonstrated. Piglets Nos 499/1 and 499/3 differentiated from conspicuously similar results in most other piglets (Tab.6). They came from a splayleg-free herd. MFH was negligible. Piglet 499/3, of the same origin, was afflicted. In Latvian LW and German LW hybrids, we may analogically assume a negative influence of the German LW breed, because the CMLW syndrome was absent in the Latvian LW x Czech LW combination (Ko l o v r a t n ík 1984).

Relevant results of older authors (B e e r m a n n et al. 1978; L u k á š et al. 1978; 
H o r á k 1979; H a n z lík o vá 1980; S u z u ki and C a s s e n s 1980b; K a m a n 1993) and data from this study show that a physiological status of porcine neonates is characterized by a full morphological and an adequate histochemical differentiation of muscle fibres. This is an indispensable condition of existence for neonates of the porcine species: they belong to nidifugous mammals (P o r t $\mathrm{m}$ a $\mathrm{n}$ 1939) whose skeletal muscles must be active immediately after birth. This is important both for neonates of the wild pig and domestic pig ( $\mathrm{K}$ a m a n 1993), particularly in large commercial herds. We absolutely cannot agree with an opinion that myofibrillar deficiency is " if not directly physiological then certainly a quite common phenomenon" in meat breeds (S c h l o tk e and K o c h 1978; M e s á r o š et al. 1979), or "partially physiological" (L o j d a et al. 1983). Our results demonstrate that MFH is an anomaly which characterizes dysmaturity of skeletal muscles. It is related to certain meat breeds of pigs, low birth body mass of piglets and type of herd management. The relationship between MFH and the CMLW syndrome in piglets can also be demonstrated by the fact that myofibrillar retardation will be compensated for morphologically, histochemically and functionally within a week after birth provided favourable conditions for the survival of affected piglets are set up ( $\mathrm{K}$ a $\mathrm{m}$ a $\mathrm{n}$ et al. 1977).

Muscles of the thoracic limb conclude their fundamental development somewhat earlier than those of the pelvic limb (M r á z k o vá 1965). This is in striking agreement with the CMLW syndrome, which affects pelvic limbs more frequently and seriously. Myofibrillar hypoplasia afects MF of the second generation. The MFH agent seems to be located in the late foetal period, to the time of MF II development. This was also indicated by an experimental decapitation of porcine foetuses at 45 days of gestation which prevented MF II differentiation and their transformation into MF of type I, and appeared immature both from the biochemical and histochemical points of view ( $\mathrm{H}$ a u s $\mathrm{m}$ a $\mathrm{n}$ et al. 1982). We believe that the reason why MFH does not affect intrafusal fibres lies in the fact that they have progressed farther in their development than extrafusal fibres ( $\mathrm{S}$ w a t l a n d 1975), i.e., their development is free of negative influences that affect the development of secondary extrafusal fibres. They generally also seem to be less vulnerable. After an experimental neonatal de-efferentation ( $\mathrm{S}$ o u k u p and Z e l e n á 1975), their histochemical and ultrastructural differentiation continues, while the differentiation of extrafusal MF is brought to a halt.

The primary MF population, most frequently represented in muscles of the $\mathrm{m}$. longissimus dorsi, i.e. phasic, type by a single primary MF (MF I) in the primary MB, develops between days 45 and 55 of gestation ( $\mathrm{T} \mathrm{h}$ u r $\mathrm{l}$ e y 1972). In the second half of gestation, 8 to 25 secondary MF (MF II) in the primary MB are formed. We believe that the blood bed, the development of which kept pace with the development of the first MF population, becomes inadequate for the development of the second population of MF. This is particularly true of meat breeds of pigs, which have been excessively selectively selected for MF of type II. Similarly as W a r d and B r a d l e y (1980), we found more clearly differentiated fibres around blood vessels.

Histochemical methods to identify regional differences in type distribution of muscle fibres in the $\mathrm{m}$. semimembranosus of porcine foetuses and neonates were used by B e e r m a n $n$ et al. (1978) and W a r d (1979) respectively. We found the same phenomenon in a number of other muscles. Their superficial portions tend to be phasic (MF II), the deeper portions tonic in character, with a larger number of MF of type I and IIC. If topographical identity of muscle excisions is not taken into account, it may lead to false conclusions on MF type distribution and misunderstandings when relevant literary data are compared.

MFH incidence in neonates corresponds - not only in the types of muscles, but also types of muscle fibres and even breeds affected - with incidence of load myopathies, including sensitivity or resistence to the halothane test (H á m or i 1980; $M$ a l' a 1983; K a m a n 1984). The muscles concerned are those with a predominance of MF II, which were already attacked 
in utero and remain more vulnerable post natum (B e r $\mathrm{g} \mathrm{m}$ a $\mathrm{n} \mathrm{n}$ and $\mathrm{W}$ e s e $\mathrm{m}$ e i e $\mathrm{r}$ 1970). Drawing an analogy between the CMLW syndrome and myasthenia gravis, $\mathrm{T} u \mathrm{c} \mathrm{e} \mathrm{k}$ et al. (1978) and $\mathrm{Z} \mathrm{r} u$ u $\mathrm{e}$ k et al. (1978) attempted to treat severe motility impairments in newborn piglets using an analogical approach based on Fysostigmin and Syntostigmin. Such an approach was doomed from the beginning because the authors disregarded the differences in pathomorphological characteristics of the two nosologic entities.

Using results of domestic and international reseach into the splayleg syndrome in veterinary medicine and animal husbandry, it was possible to successfully reduce the initial explosion of its incidence. A survey made between 1984 and 1990 by the Institute of Veterinary Genetics in Brno (Há j k o va 1992) showed that the curve of its incidence was more or less flat, with a total average of $1.94 \%$. For a number of reasons, its real incidence was undoubtedly higher. It remains as one of topical problems of pig rearing because its etiology has not been successfully understood yet.

At present, there is much evidence that these "modern" porcine myopathies have a common denominator in one-sided excessive selection of pigs for meat, particularly for muscle groups with an absolute predominance of extrafusal muscle fibres of type II, which are very vulnerable. If the existing situation is to be changed, it will be necessary to make assessment of parent pairs from the point of view of maturity of muscle fibres of their litter.

\section{Morfologická a histochemická typová diferenciace svalového vlákna novorozeného prasete ve vztahu $k$ aktuálním myopatiím}

Zkoumali jsme u 7 topograficky a funkčně rozličných svalů novorozeného selete prasete divokého, primitivního plemene domácího a deseti moderních plemen různého stupně vyšlechtění a jejich hybridů $s$ cílem zjistit stav diferenciace svalového vlákna (SV) novorozeného prasete jako druhu. Konfrontací reakce myozinové ATPázy po kyselé a po alkalické preinkubaci jsme rozlišili SV typu I, II a intermediární typ IIC s jeho transformačními podtypy MS, SS a SM ve SV typu I. Někdy jsme zaznamenali i diferenciaci SV II ve SV IIA a SV IIB. Detekce SDH a reakce PAS spolehlivě, respektive vůbec typově SV novorozenců nerozlišila.

Stupeň diferenciace SV novorozeného selete souvisel s jeho porodní hmotností, typem SV a jejich vztahu ke krevnímu řečišti a především s plemennou příslušností jedince. Svalová vlákna byla plně morfologicky a adekvátně histochemicky diferencována u neonátů prasete divokého, primitivního domácího a u méně vyselektovaných plemen prasete domácího. Moderní masná plemena vykazovala, $v$ rozsahu fyziologické variační šíre, myofibrilární deficit ojedinělých SV u středně vyšlechtěných plemen. Rủzně intenzivní až těžká myofibrilární hypoplazie (MHF) charakterizovala plemena intenzívně šlechtěná na extrémní nárůst svaloviny. MHF postihovala preferenčně extrafuzální, anaerobní SV II a svalové skupiny s dominancí SV II, na které jsou tato plemena jednostranně šlechtěna.

Myofibrilární hypoplazií nebyla atakována intrafuzální SV.

\section{References}

ASHMORE, C. R., ADDIS, P. B., DOERR, L. 1973: Development of muscle fibers in fetal pig. J. Anim. Sci., 36:1088-1093

BEERMANN, D. H., CASSENS, R.G., HAUSMAN, G. J. 1978: A second look at fiber type differentiation in porcine skeletal muscle. J. Anim. Sci., 46:125-132

BERGMANN, V., WESEMEIER, H. 1970: Elektronmikroskopische Befunde an der Skelettmuskulatur bei Fleischschweinen. Arch. exper. Vet. med. 24:1241-1255

BRADLEY, R., WARD, P. S. , BAILEY, J. 1980: The ultrastructural morphology of the skeletal muscles of normal pigs and pigs with splayleg from birth to one week of age. J. Comp. Path. 90:433-446

BUČEK, J., LUKÅS, Z., PIVNIK,L., KAMAN, J. 1982: Muscle ultrastructure in newborn piglets with splayleg syndrome, Acta vet. Brno 51:47-58 
COX, C.S., WARD, P. S., BASKERVILLE, A. 1979: Quantitative image analysis of skeletal muscle from newborn pigs with myofibrillar hypoplasia and splayleg. Brit. Vet. J., 135:370-375

DUBOWITZ, V., BROOKE, M. H. 1973: Muscle biopsy: A modern approach. Saunders Company Ltd. London, $475 \mathrm{p}$.

HÁMORI, D. 1980: Reproductive-hygienic studies in large animal herds. II. Data on the incidence of the pale soft exudative meat syndrome among various pig breeds, its genetic causes. Magyar Állatorvosok Lapja 35:525-529

HÁJKOVÁ, J. 1992.: Personal communication

HAUSMAN, G. J., CAMPION, D. R., THOMAS, G. R. 1982: Semitendinosus muscle development in fetally decapitated pigs. J. Anim. Sci. 55:1330-1335

HANZLIKOVA, V. 1980: Histochemical patterns in normal and splaylegged muscle fibers. Histochemistry 67:311319

HORÁK, V. 1979:Heterogenita a ontogenetický vývoj typủ svalových vláken u miniprasat a drůbeže. PhD. Thesis, Liběchov $174 \mathrm{p}$.

JIRMANOVÁ, I. 1983: The splayleg disease: A form of congenital glucocorticoid myopathy? Vet. Res. Com. 6:91101

KAMAN, J. 1984:Vztah mezi stupněm diferenciace svalového vlákna novorozeného a anomáliemi kosterní svalovinypostiženého jatěného prasete. Jakostní vady veprového a hovězího masa. Abstracts, VŠZ Brno, p. 14

KAMAN, J. 1993: Morphological and histochemical type differentiation of muscle fibres in newborn piglets of the Vietnamese breed. Acta vet. Brno 62:139-149

KAMAN, J. Postnatal morphological and histochemical type differentiation of muscle fibres in the pig. Acta vet. Brno, in press

KAMAN, J., PIVNIK, L., LUKÁŠ, Z. 1977: Retardation phenomenon in histogenesis of the muscle fibres of the fleshy type of pig. Folia morphol. 25:360-363

KOLOVRATNIK, Z. 1993: Personal communication

LOJDA, Z., PAPOUŠEK, F. 1978: Základy histochemického průkazu enzymů. Ústav pro další vzdělávání zdravotnických kádrù. Brno, 119

LOJDA, L., HOŘ́NOVÁ, Z., LOJDA, Z., BÖHM, R. 1983: Experimentální prùkaz hlavního etiologického faktoru pri vzniku syndromu svalové slabosti končetin selat (splayleg). Ústav veterinární osvěty, Pardubice, $17 \mathrm{p}$.

LUKÁS, Z., PIVNIK, L., STRAKA, I., RAMPOCHOVÁ, J., ŚTÉPÂNOVÁ, L., KAMAN, J. 1982: Morphological and histochemical type differentiation of the primary and secondary foetal muscle fibres in neonatal piglets. Zbl. Vet. Med. A 29:107-122

MALA, P. 1983: Analýza fyziologických vlastností ošípaných a diagnostických ukazatelov kvality mäsa vo vztahu k reakcii na halotanový test. PhD. thesis, Inst. Exp. Vet. Med., Košice

MESÁROŠ, E., PIVNIK, L., VAREJČKO, J., REHÁK, A. 1981: Zbavíme se "roznožky" selat? Veterinářství 31:266-268

MRÁZKOVÅ, O. 1965: Changes of diameter of muscle fibres in corresponding muscles of upper and lower limb observed during fetal development. Fol. Morphol. 13:265-274

PIVNIK, L., KAMAN, J. 1975: Výzkum některých poruch motility novorozených selat. Project report VII-6-4/8, VŠV Brno, $67 \mathrm{p}$.

PORTMANN, A. 1939, In: ŠTĚRBA, O.1984: Ontogenetic patterns and reproductive strategies in mammals. Fol. Zool. Brno, 33:65-72

SEDLAK, M. 1980: Occurrence of the splayleg syndrome in piglets from the state farm Velké Albrechtice in line groups of sows and boars in years 1977-79. Thesis, Veterinary Univ. Brno, 32 p. (in Czech)

SCHLEGEL, O. 1982: Untersuchungen über die Fasertypenverteilung und Fasertypenquerschnittsflächen in m. longissimus dorsi und M. semitendinosus von trainierten Haus- und immobil gehaltenen Wildschweinen. Inaug. Diss., Tierärztl. Hochschule, Hannover (in German), 92 p.

SCHLOTKE, B., KOCH, F. 1978: Histochemische Untersuchungen zur Entwicklung der Skelettmuskulatur des Ferkels in der Neugeborenenphase. Zbl. Vet. Med. A 25:129-137

SOUKUP, T., ZELENÁ, J. 1975: Different response to motor denervation of muscle fibres. Fol. Morphol. Praha 23:278-281

SUZUKI, A., CASSENS, R. G. 1980a: pH sensitivity of myosin adenosine triphosphatase and subtypes of myofibers in porcine muscle. Histochem. J. 12:687-693

SUZUKI, A., CASSENS, R. G. 1980b: A histochemical study of myofiber type in muscle of growing pig. J. Anim. Sci. 51:1449-1461

SWATLAND, H. 1975: Myofibre number and myofibrillar development in neonatal pigs. Zbl. Vet. Med. A, 22:756763

THURLEY, D. C. 1972: Increase in diameter of muscle in the foetal pig. Brit Vet. J. 128:355-358

THURLEY, D. C., DONE, J. T. 1969: The histology of myofibrillar hypoplasia of newborn pigs. Zbl. Vet. Med. A, 16:732-740

TUČEK, S. et al. 1978: Histochemické a ultrastrukturální změny pri roznozce selat a pokus o jejich terapeutické ovlivnění. Celostátní seminár̆ o splaylegu. Sborník referátủ. Vyd. : ÚVO Pardubice, pp. 1-4

WARD, P. S. 1979: Cit. in: Cox, Ward, Baskerville 1979: Brit. Vet. J. 135, 370-375

WARD, P.S., BRADLEY, R. 1980: The light microscopical morphology of the skeletal muscle of normal pigs and 
pigs with splayleg from birth to one week of age. J. Comp. Pathol. 90:421-431

ZELENA, J., JIRMANOVÁ, I. 1979: Degenerative changes in skeletal muscles of piglets with congenital myofibrillar hypoplasia. Zbl. Vet. Med. A 26:652-665

ZRƯNEK, A., BILÁ, J., ŠTEFAN, M. 1977: Hodnocení účinku Syntostigminu při pokusné terapii svalové slabosti končetin narozených selat. Veterinářství 27:454-457

* Address for correspondence:

Sumavská 25

60200 Brno

Czech Republik 
Plate XIV.

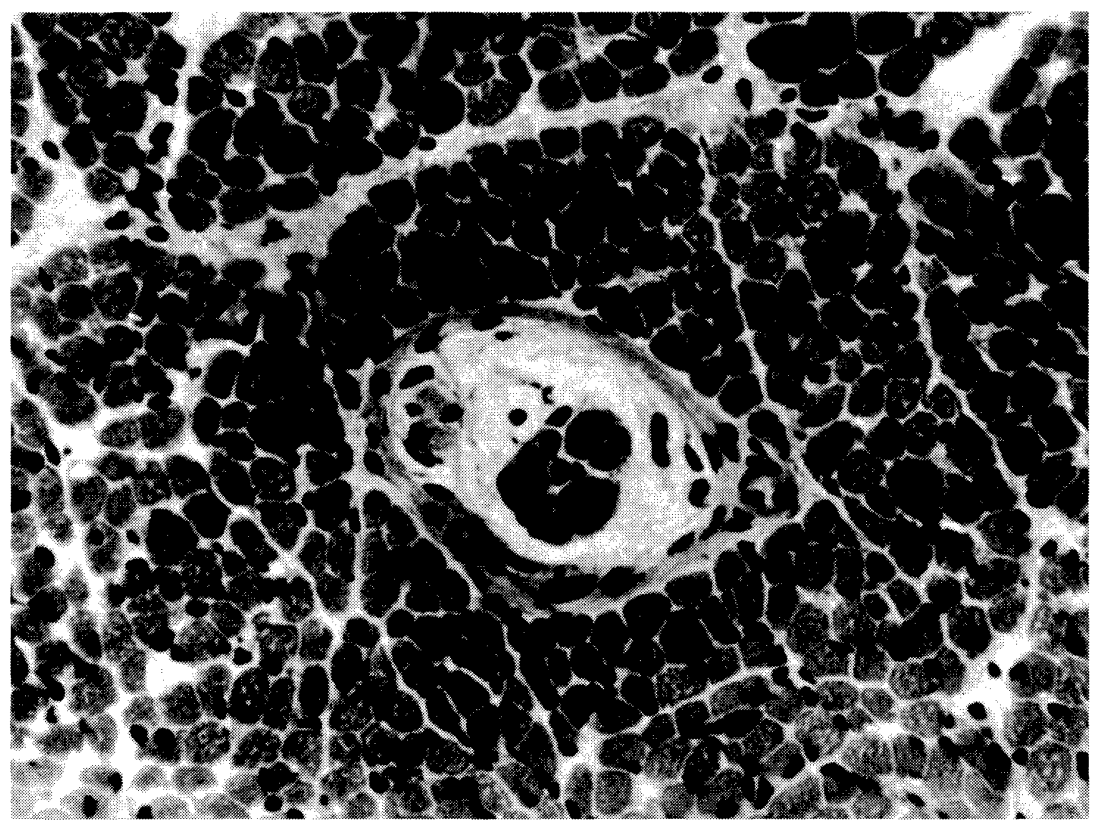

Fig. 1. Transversal cryostat section, Sus scrofa, m. longissimus dorsi. Complete morphological differentiation of extra- and intrafusal muscle fibres (MF), characterized by complete myofibrillar filling the MF, equal thickness of both developmental stages of fibre populations (MF I : MF II), polygonal CS and subsarcolemally localized cell nuclei, which, in intrafusal MF, are located mostly intrafibrally, and these fibres are clearly of different thickness. Hematoxylin-eosin (HE), x 160.

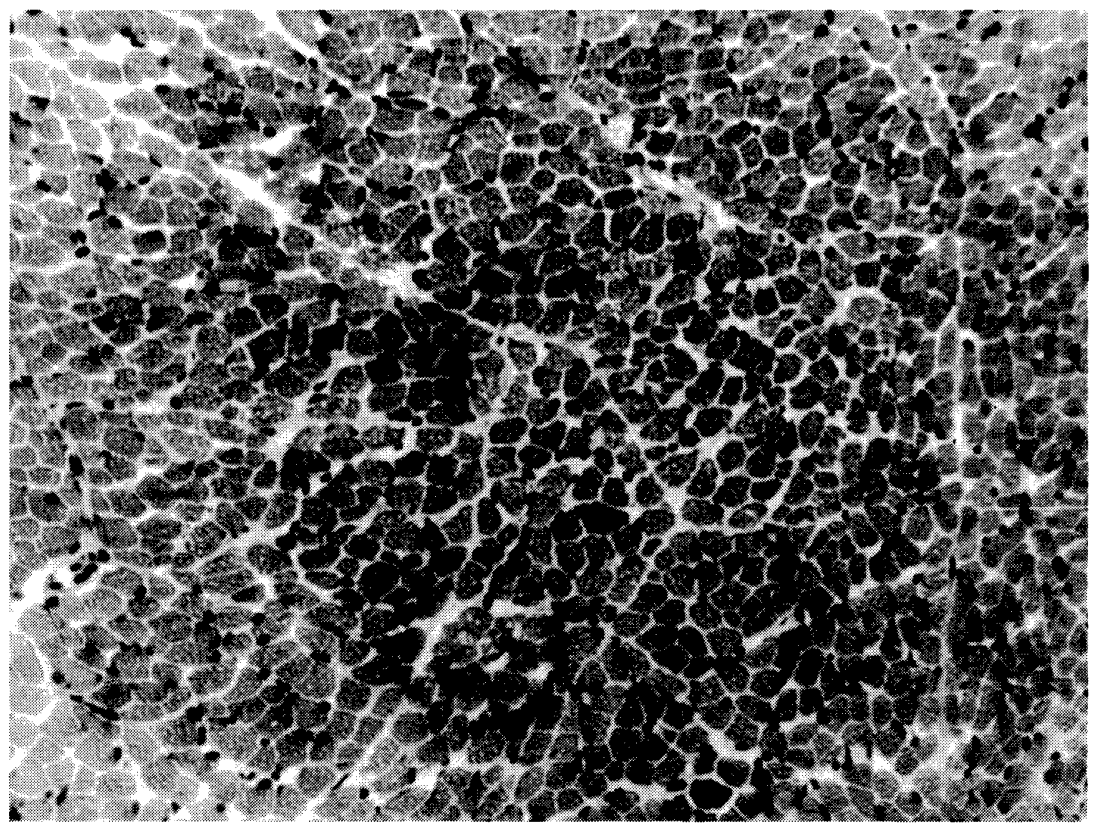

Fig. 2. Hybrid (BL x Duroc), m. sternomastoideus. Complete differentiation of extrafusal MF. Sporadic cell nuclei located intrafibrally. Transverse cryostat section (TC), He, x 100. 


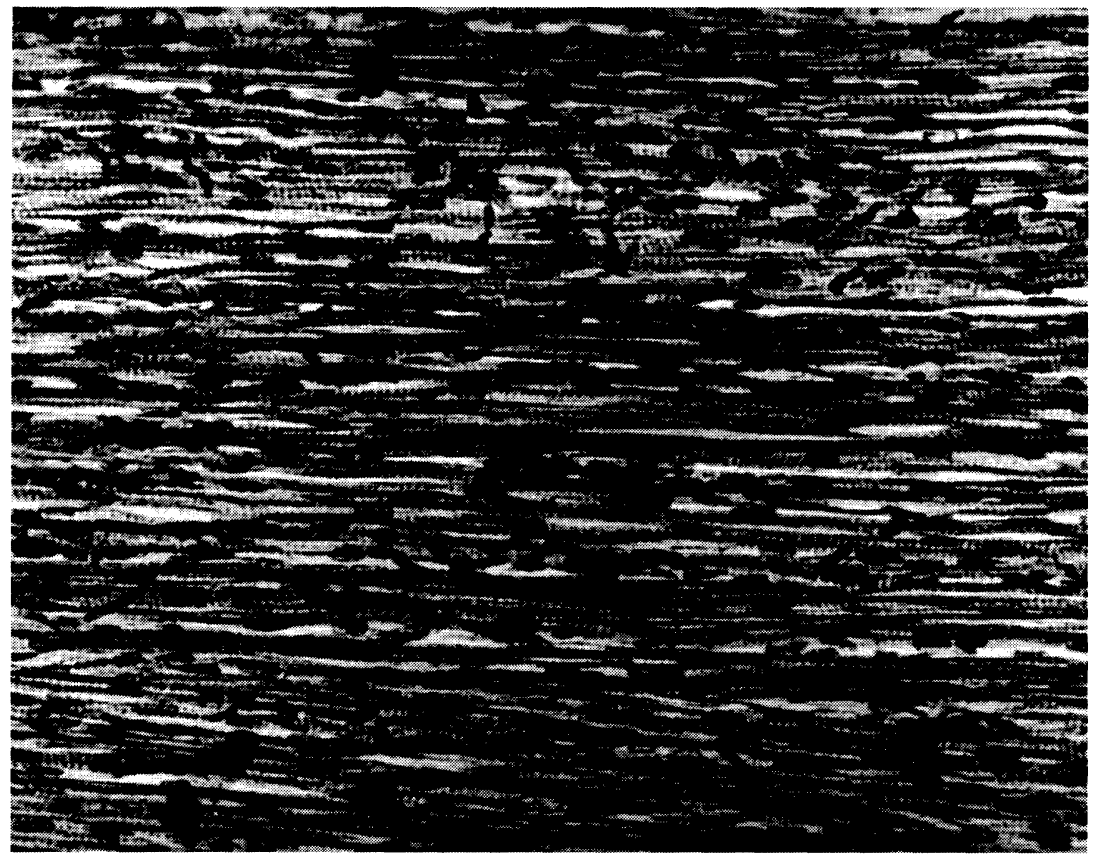

Fig. 3. Hybrid (Pc x L), m. gracilis, longitudinal paraffin section (LP). Complete differentiation is also demonstrated by fully developed striation of muscle fibres. HE, x 160.

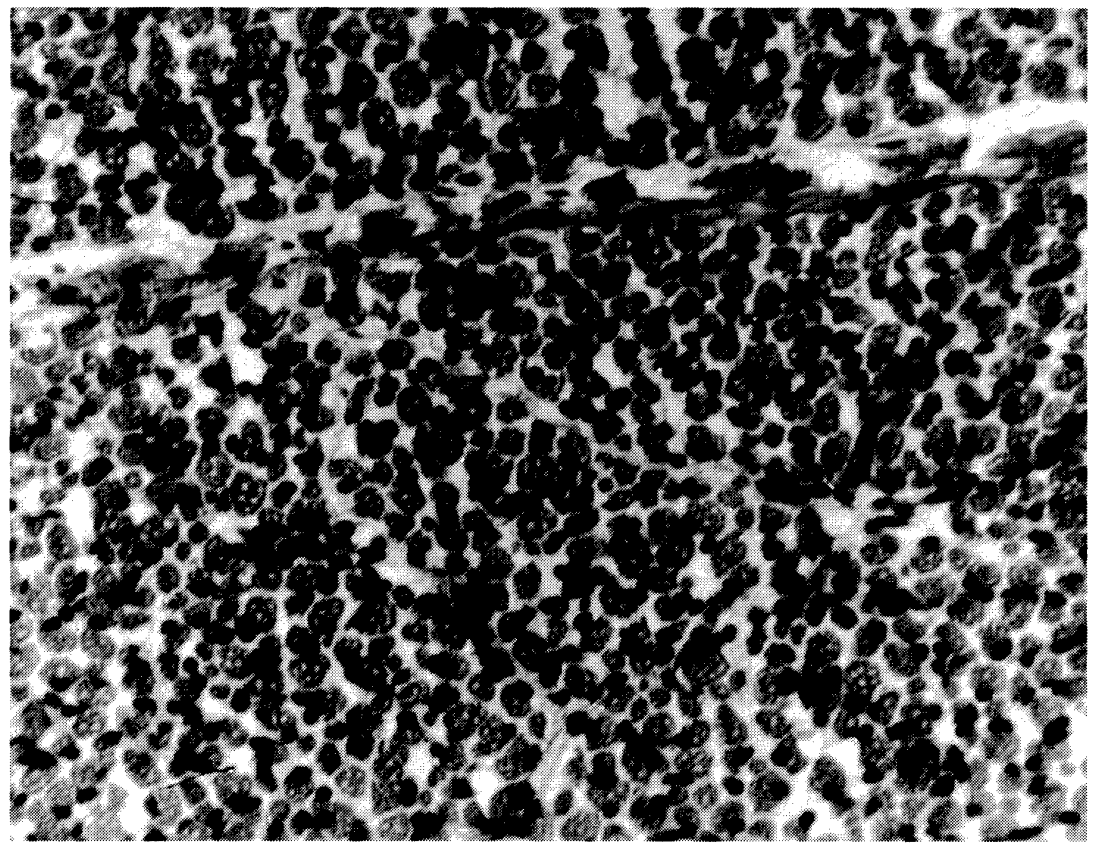

Fig. 4. Duroc, m. semimembranosus. Extrafusal muscle fibres are fully filled with myofibrils, the diameter of both populations has been equalized to a large extent, although their CS is still predominantly circular. In spite of well-defined interstitium, muscle bundles (MB) cannot be differentiated, and homogenous tissue predominates. TC, HE, x 80. 


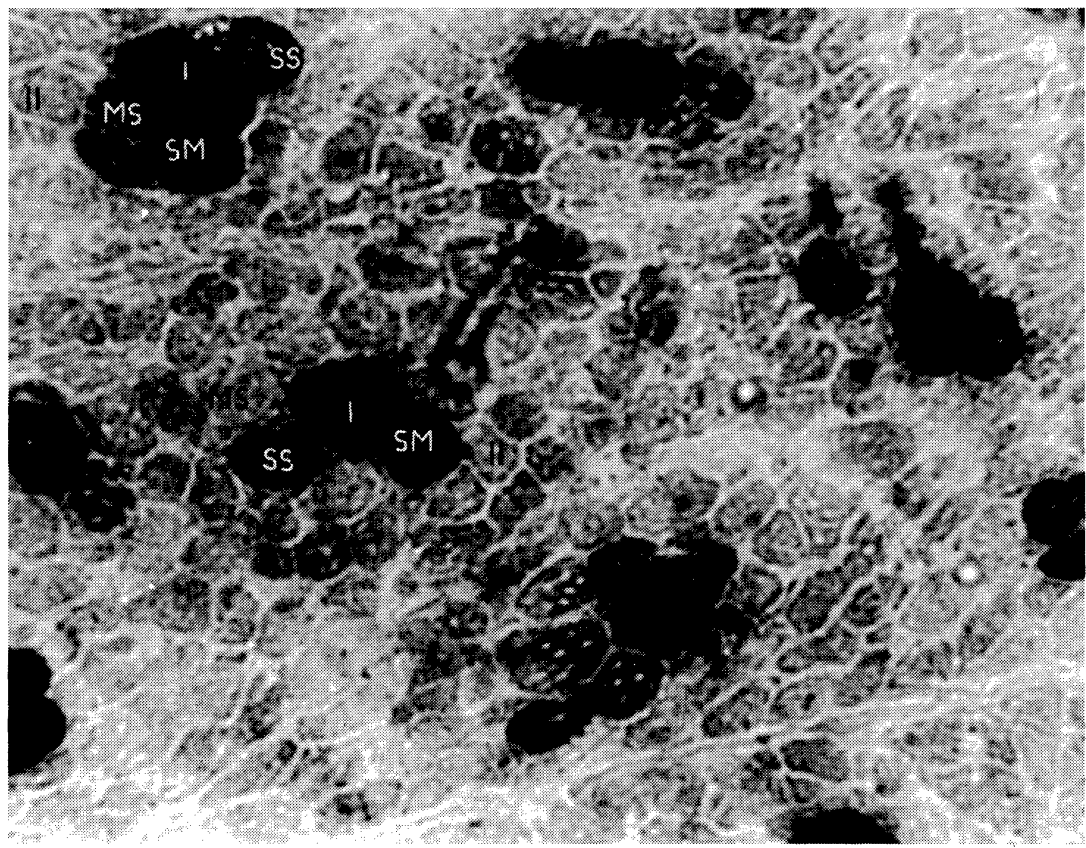

Fig. 5a. Sus scrofa, m. longissimus dorsi. Myosin Ca-ATPase activity after preincubation at $\mathrm{pH} 4.3$ is clearly graduated and it differentiates between MF types I, II and intermediary IIC with transformation subtypes MS, SS and SM, x 252.

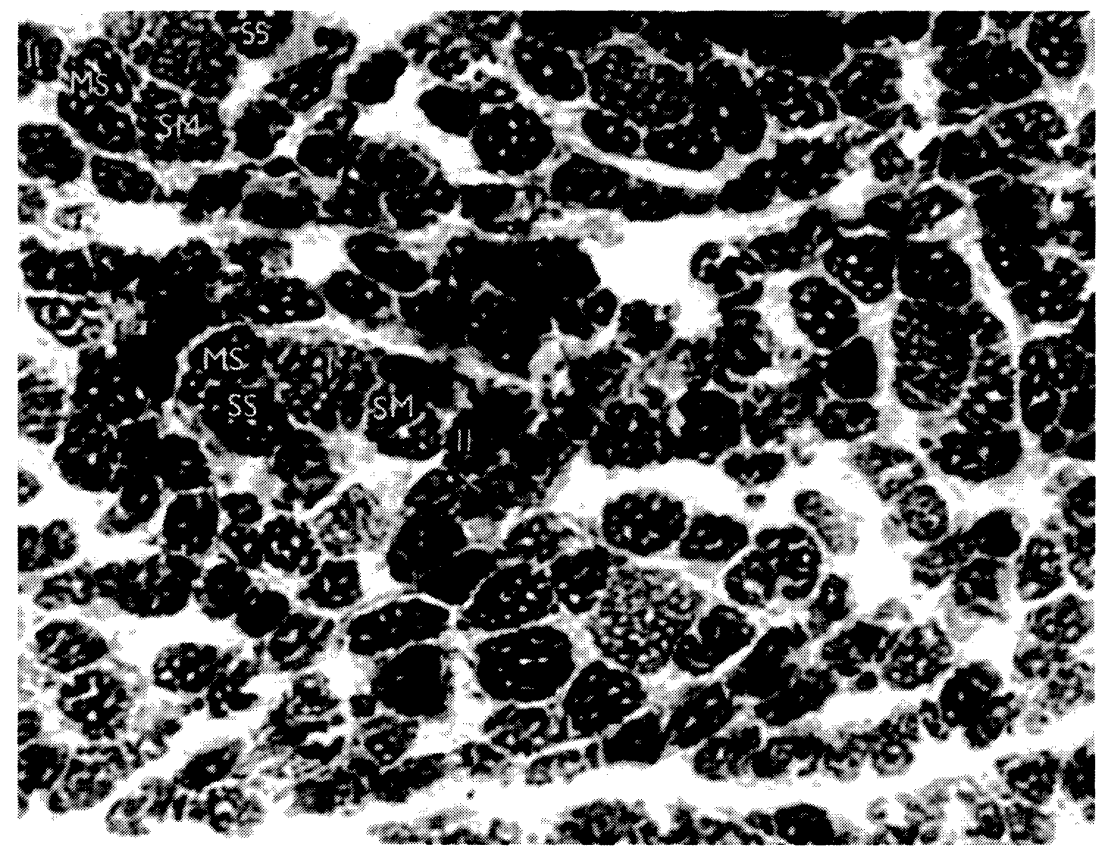

Fig. 5b. Serial section complementing Fig.5a. Myosin Ca-ATPase activity after alkaline preincubation at $\mathrm{pH} 9.4$ presents an inverse picture of the myosin $\mathrm{Ca}$-ATPase response after acid preincubation. 


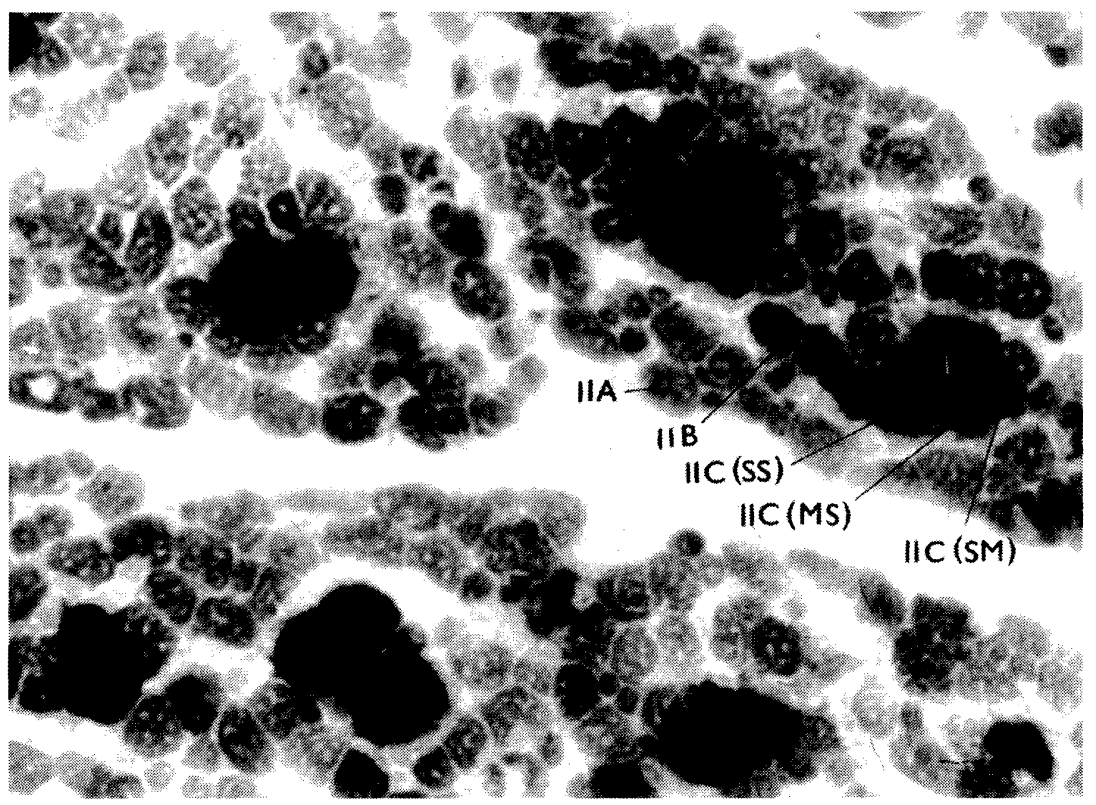

Fig. 6. Sus scrofa, m. longissimus dorsi. Myosin Ca-ATPase reaction after acid preincubation at $\mathrm{pH} 4.6$ differentiated not only fibres of the type I and II, but also of type IIC and its subtypes MS, SS and SM. In some places, muscle fibres of type II have differentiated into types IIA and IIB, x 252 .

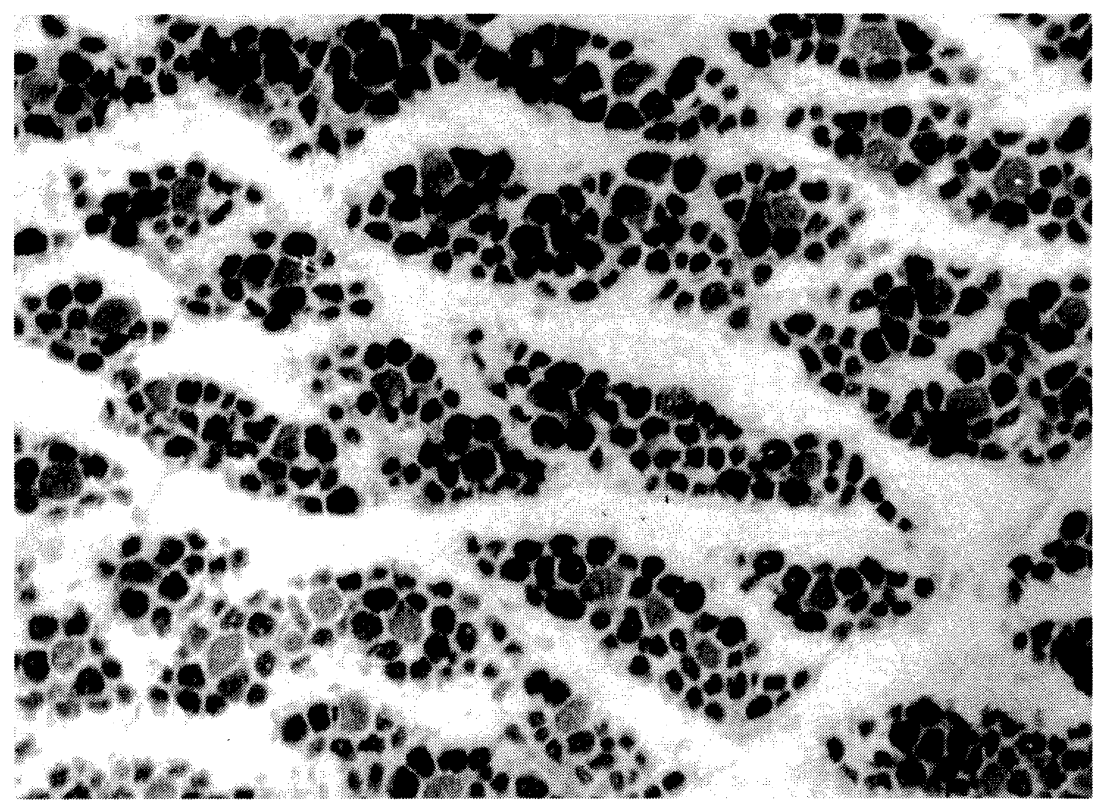

Fig. 7. Transverse sections from a superficial portion of the $\mathrm{m}$. longissimus dorsi of a Vietnamese piglet are characterized by markedly wide interfascicular areas and clearly defined muscle bundles (MB). In some places, weakly-reacting primary MF predominate by their thickness in the centre of primary MB. Alkaline ATPase was able to differentiate all basic MF types, i.e. types I, II and IIC; $\mathrm{x} 80$. 


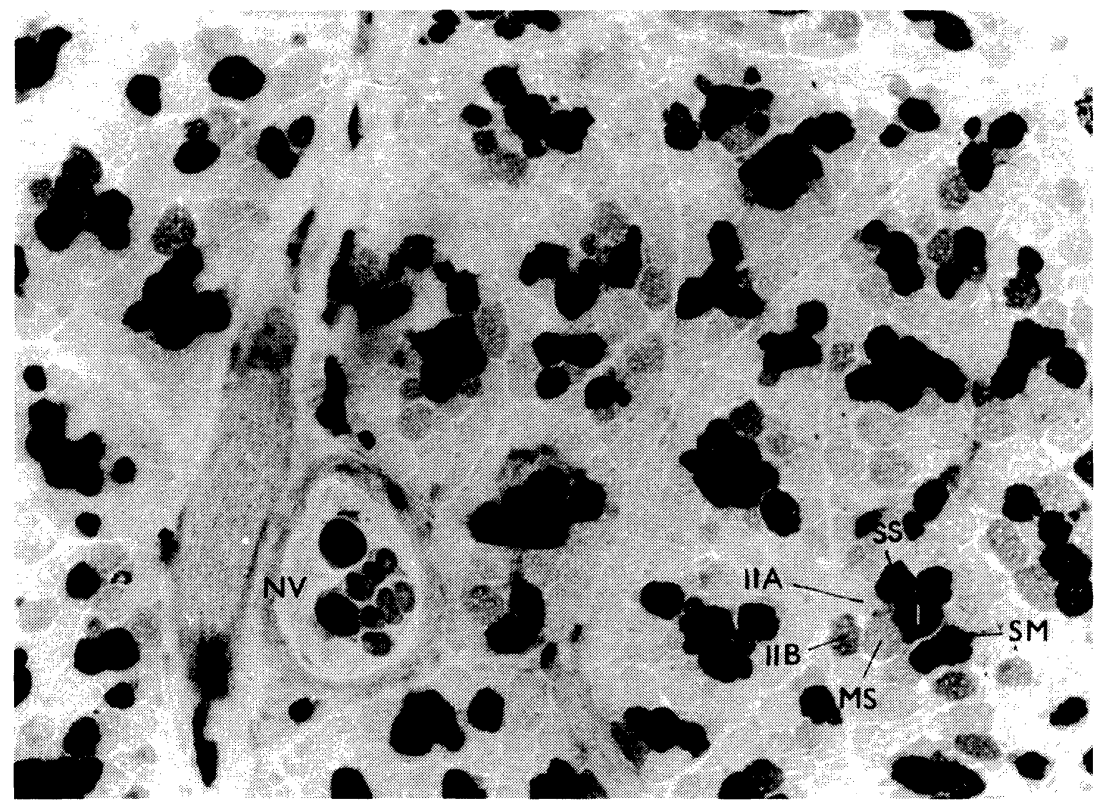

Fig. 8a. Belgium Ladrace. M. sternomastoideus. Ca-ATPase reaction after acid preincubation at $\mathrm{pH}$ 4.6 showed a high degree of differentiation. Compared to Fig.5a, the number of acid stable fibres is markedly high. A comparison with an inverse situation at $\mathrm{pH} 9.4$ (Fig.8b) shows that not all intensively reacting fibres are of type I, but that they also include the SM (light black), SS (dark grey) and MS (grey) subtypes. Type IIA fibres do not react at all or stain light grey only. Most frequently, primary Mbs contain 1-3 Type I fibres. The reaction of intrafusal fibres identifies them as fibres of type II, I and the SS subtype. NB = neuromuscular bundle; $x 101$.

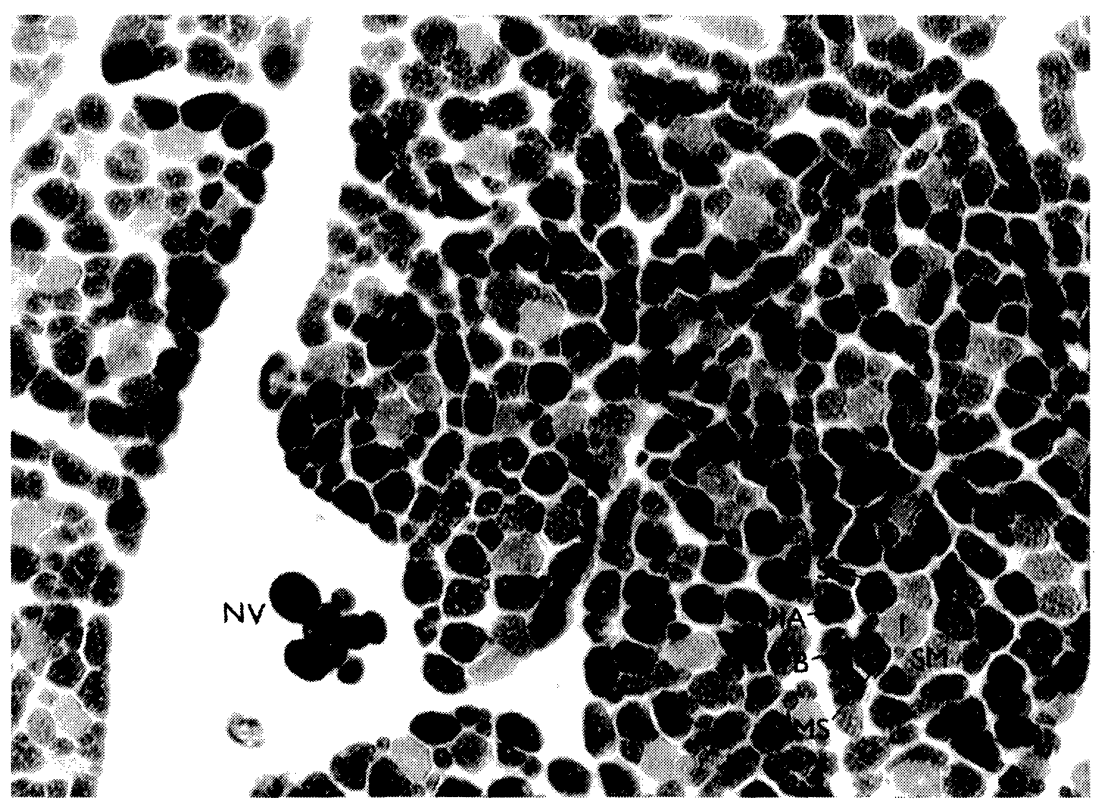

Fig. 8b. Serial section, inversion of Fig. 8a. Alkaline Ca-ATPase at pH 9.4. Primary MB usually contain 1-3 type I fibres. 


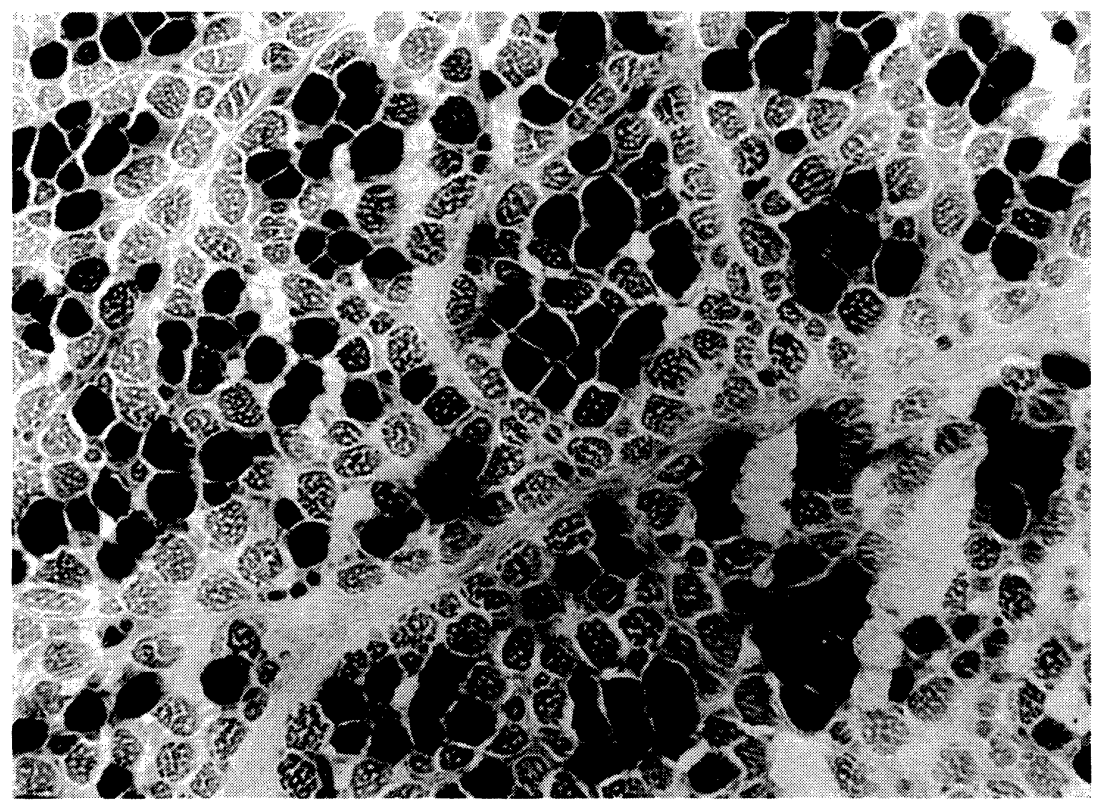

Fig. 9a. M. trapezius - highly differentiated, with an intensive enzymohistochemical reaction. CaATPase after preincubation at $\mathrm{pH} 4.3$ shows a large number of MF I (black), and tone-graded MS, SS and SM fibres (converging to MF I), which, in some primary MB, predominate in quantity over MF II. Duroc, x 101.

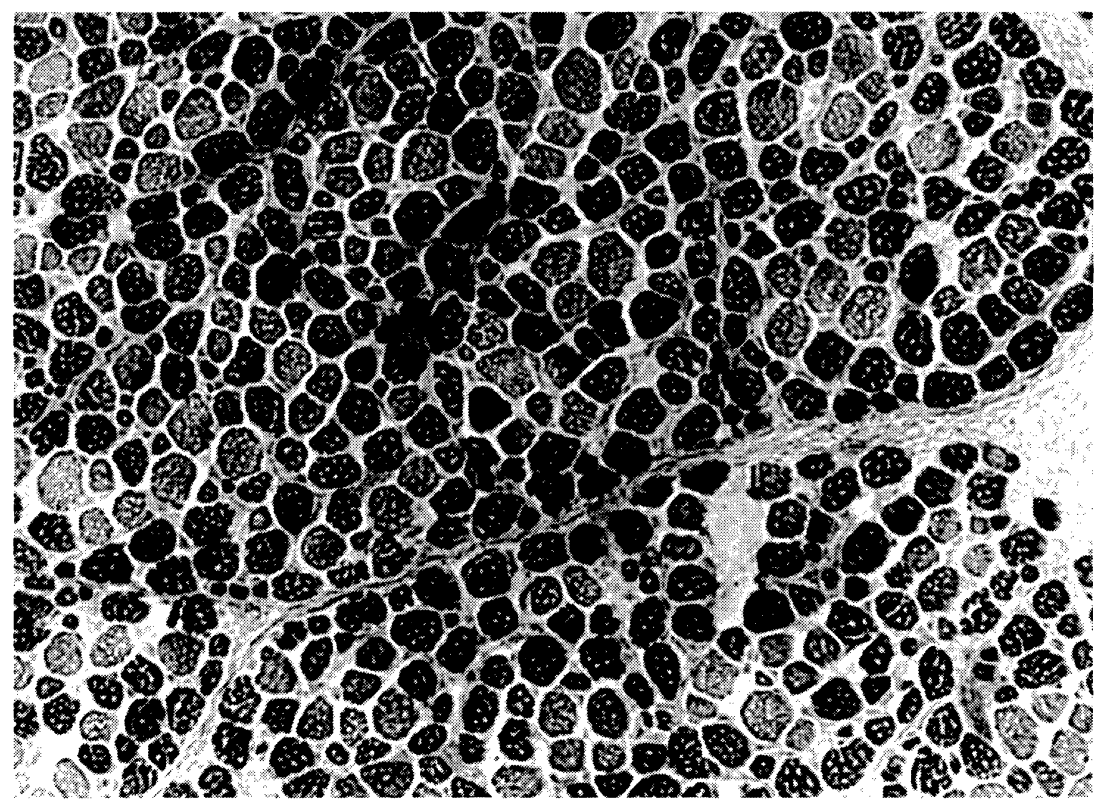

Fig. 9b. Inversion of Fig.9a. Myosin ATPase, preincubation at pH 9.4. Reaction and differentiation highly conclusive. The least reactive were MF I, the most reactive MF II; an intermediate differentiated reaction was observed in MS and SS subtypes; $x 101$. 


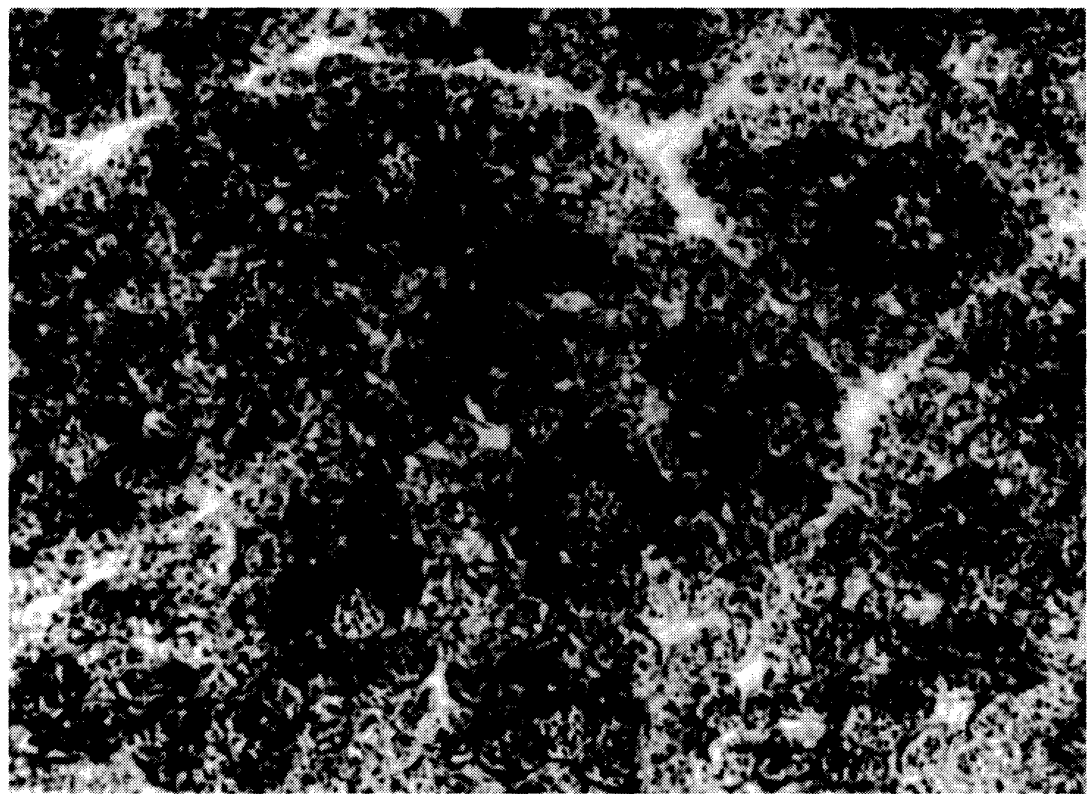

Fig. 10. SDH reaction. Product of the reaction is accumulated interfibrilarly and subsarcolemally (intensity higher in the centre of the primary $\mathrm{MB}$ ) in fibres corresponding to types I and IIC. An objective differentiation from other fibre types, or differentiation of type II fibres among themselves is mostly impossible. Duroc, m. triceps brachii, c. longum; x 160.

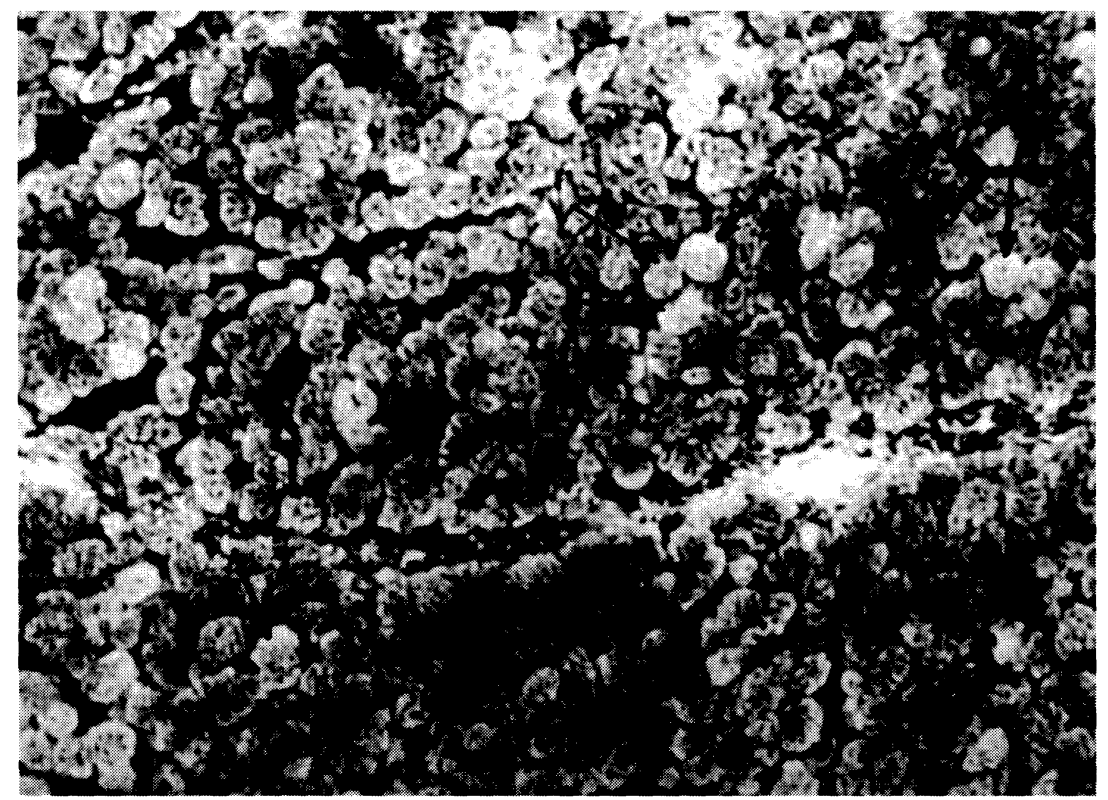

Fig. 11. PAS reaction. Glycogen not only interfibrilarly but also interfascicularly. Intrafibrial reaction is graded in places, weaker in MF IIC and particularly in MF I (arrowed). Duroc, $\mathrm{m}$. gracilis, $\mathrm{x} 160$. 
Plate XXI.

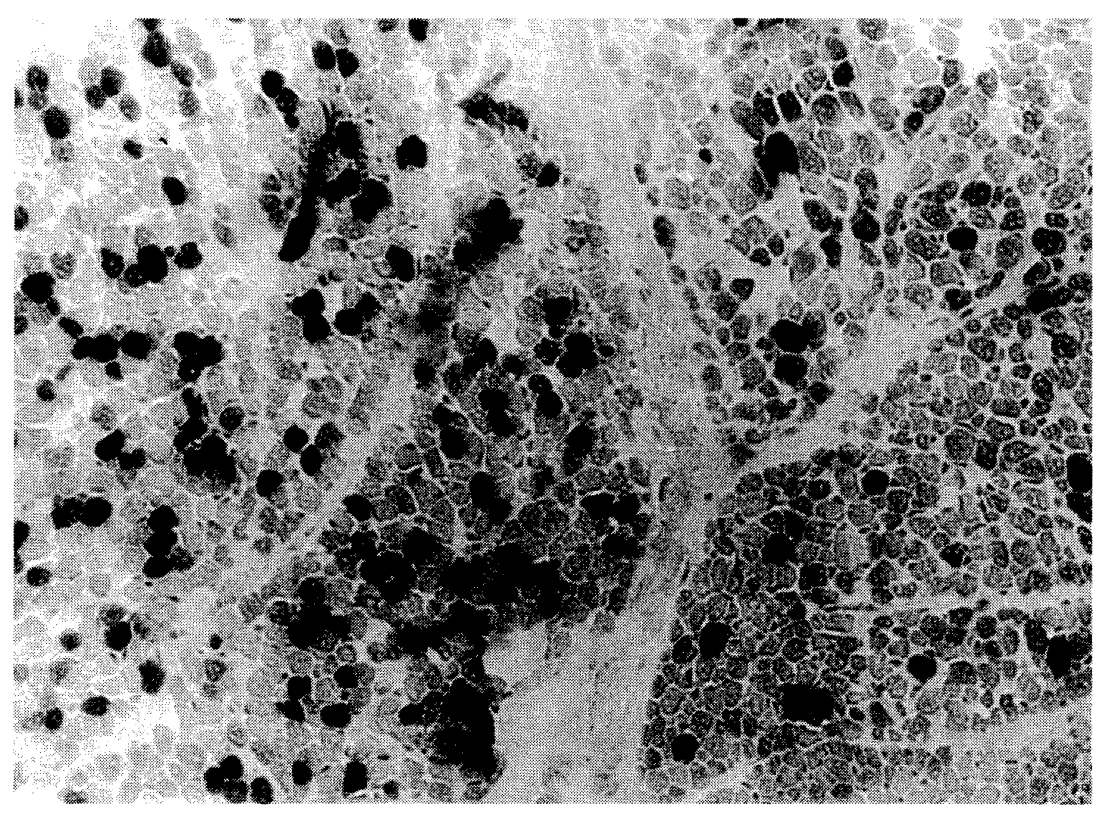

Fig. 12. Histochemical variety in morphologically uniform the superficial and the deep portions of the $\mathrm{m}$. semimembranosus. The number of type I and IIC fibres in the muscle's deep portion (left) is clearly larger than in the superficial one (right). Duroc, Ca-ATPase after preincubation at $\mathrm{pH} 4.6$; $\mathrm{x} 101$.

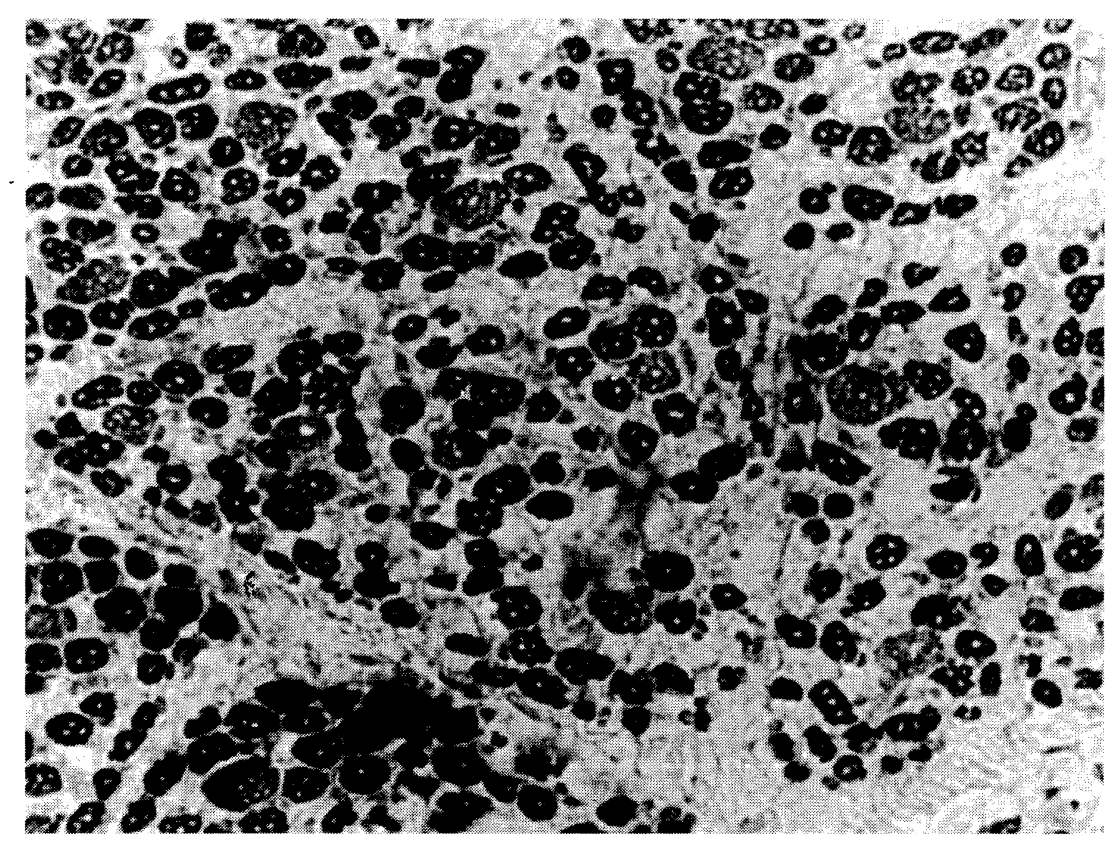

Fig. 13. Landrace, m. longissimus dorsi, Ca-ATPase at $\mathrm{pH} 9.4$. Generally somewhat lower morphological differentiation. A marked disproportion between very thick MF I and significantly thinner MF II, particularly in the right half of the image. Sporadic remains of the myotube lumen. Very intensive histochemical reaction with a clear differentiation of MFs I; x 160. 


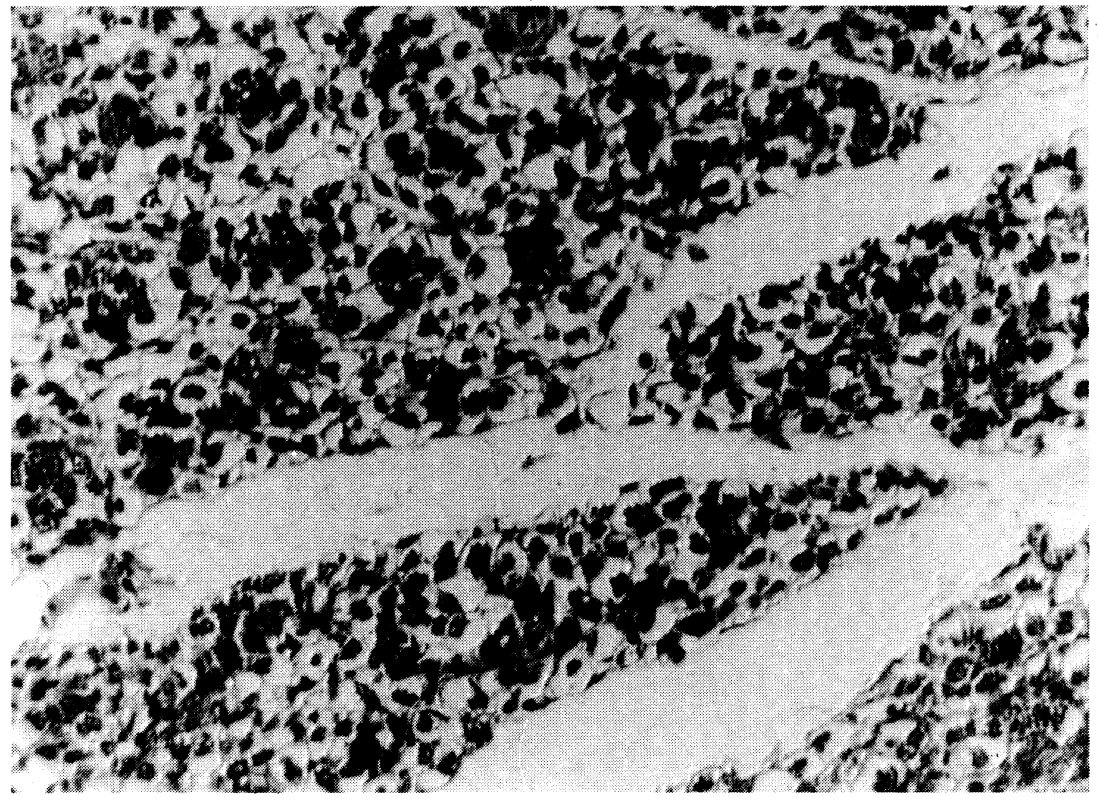

Fig. 14. M. semimembranosus, Large White $\mathrm{x}$ Landrace, transversal paraffin section. Heavy and extensive myofibrillar hypoplasia. HE, x 80.

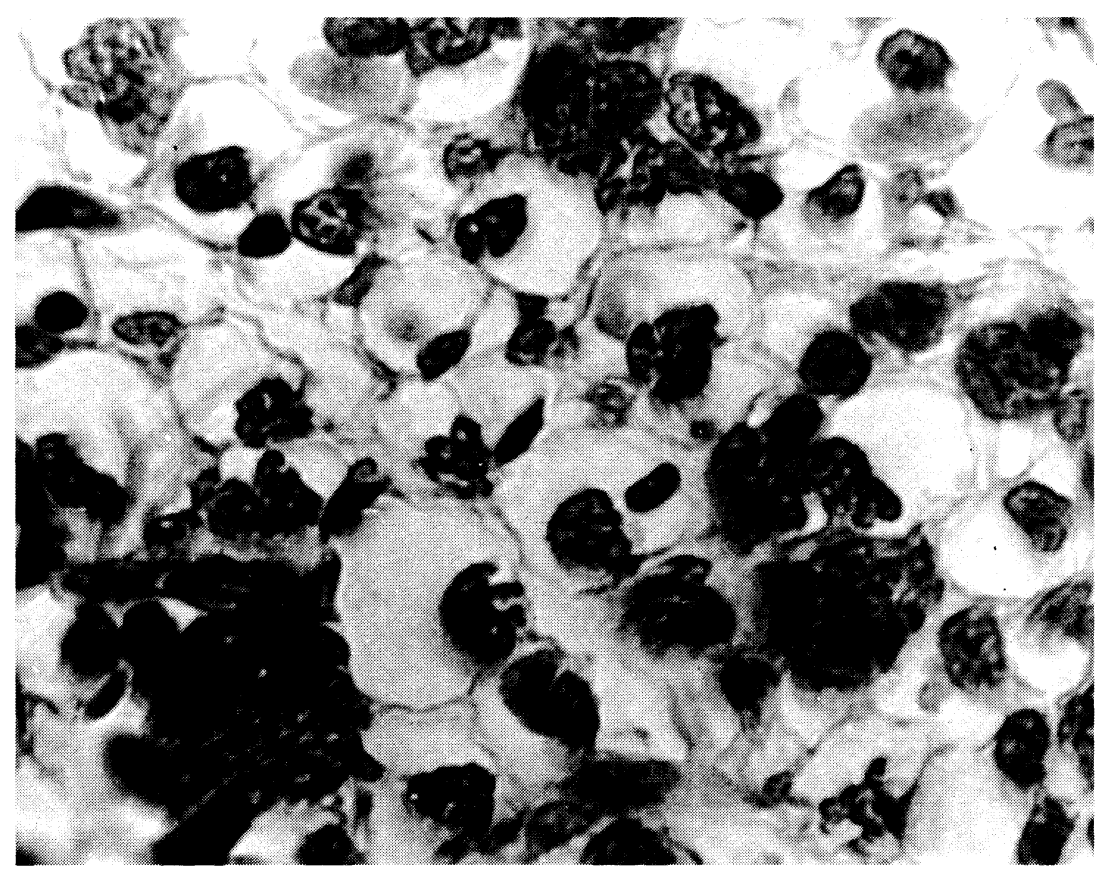

Fig. 15. Enlarged detail from Fig.15. In fibres with $100 \%$ myofibrillar deficiency, we find a clear demarcation by the sarcolemma; in other respects, it is visually empty or with an intrafibrally located cell nucleus; $\mathrm{x} 360$. 